\title{
INDIGENOUS PERSPECTIVES ON CORPORATE GOVERNANCE
}

\author{
Grant Christensen*
}

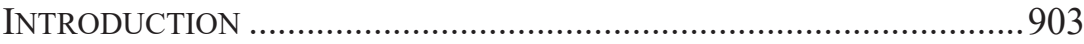

I. THE TRADITIONAL MODEL OF CORPORATE GOVERNANCE ..........908

A. The Origins of Shareholder Primacy ................................910

B. The Intervening Role of the Business Judgment Rule ......912

II. THE NEED to RETHINK SHAREHOLDER PrimACY ........................914

III. INDIGENOUS CORPORATIONS ..................................................... 917

A. Chthonic or Autochthonous Law .....................................918

B. Autochthonous Governance .............................................923

1. Indigenous Corporations under the Indian

Reorganization Act ................................................924

2. Alaska Native Corporations.......................................926

3. Tribal Incorporation Codes .......................................929

4. International Indigenous Corporations .......................932

IV. INDIGENOUS CORPORATE GOVERNANCE .................................934

A. Time Horizons and the Elimination of Short-Termism ....937

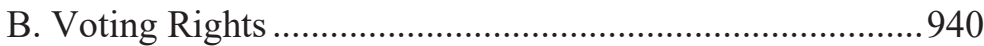

1. Maturity of Voting Rights ........................................940

2. Shares with Variable Voting Rights ...........................944

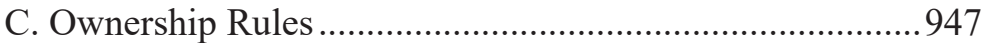

1. Stakeholder Ownership.............................................948

2. Corporate Shares as Life Estates ...............................951

V. CONCLUDING OBSERVATIONS ....................................................993

\footnotetext{
* Grant Christensen is now an Assistant Professor of Law at Stetson and was formally an Associate Professor of Law and Affiliated Associate Professor of American Indian Studies at the University of North Dakota. He holds an L.L.M. in Indigenous Peoples Law \& Policy from the University of Arizona and a J.D. from Ohio State. I would like to thank Beate Sjåfjell, Christopher Bruner, and the other amazing contributors to the Cambridge Handbook of Corporate Law, Corporate Governance, and Sustainability for encouraging me to continue working on the intersection of Indigenous law and corporate governance. I also owe a debt of gratitude to the organizers and participants at the 2019 Central States Law School Association Conference, the $10^{\text {th }}$ Annual Constitutional Law Colloquium at Loyola School of Law, and the 2019 Polar Law Symposium for letting me present different portions of this work and providing invaluable insight and commentary to help make it stronger.
} 


\section{ABSTRACT}

The foundation of the modern corporation is built upon the separation of labor and capital. These entities were anathema to most Indigenous peoples when the Virginia Company was chartered in 1606 for the purpose of settling American lands. Over centuries of colonization federal law worked to assimilate Native Americans. Tribes were encouraged, even forced, to create their own corporate entities. Indelibly, consistent with their inherent sovereignty, Indigenous groups fused autochthonous legal principles into these corporate structures. Today, in the shadow of the \#BLM movement and societal demands that corporations become more responsive to their communities and to the environment, shareholder primacy has reached its nadir. As corporate governance seeks to replace it with something stakeholder centered, autochthonous principles gleaned from Indigenous corporations offer a way forward. These proposed reforms are as varied as the chthonic law they are built upon and range from making nature itself a corporate shareholder to issuing shares that gain voting rights only after they have been held to maturity.

Leaders of Indian nations must understand that long-standing tribal values, customs, and traditions are sources for problemsolving, not only in the legal arena but also in areas like health and social welfare, education, and government. This process of looking inward for solutions can be described as Indian peoples doing self-government and self-determination the Indian way, by drawing on Indian thinking and long-used Indian methods and normative precepts to solve community problems. - Justice Raymond Austin (Navajo Supreme Court) ${ }^{1}$

\section{INTRODUCTION}

The law has long presumed that corporations are run for the benefit of their shareholders. ${ }^{2}$ While the doctrine of shareholder primacy has been functionally unchallenged for generations, ${ }^{3}$ over the last twenty years

1. Raymond Austin, American Indian Customary Law in the Modern Courts of American Indian Nations, 11 Wyo. L. REV. 351, 354 (2011).

2. See Eric Chaffee, Collaboration Theory and Corporate Tax Avoidance, 76 WASH \& LEE L. REV. 93 (2019) (discussing the origins of corporate law and summarizing the Dodge case's "a for-profit corporation must be run to make a profit." Chaffee goes on to argue this duty does not extend to tax avoidance).

3. Robert Rhee, A Legal Theory of Shareholder Primacy, 102 MinN. L. REV. 1951, 1953 
investors, managers, and directors have faced mounting pressure to account for a broader range of objectives when making governance decisions, including the interests of employees and the environment. In August 2019, in what is considered a watershed moment for corporate governance, ${ }^{4}$ the Business Roundtable suggested that corporations should be run with their stakeholders in mind: "While each of our individual companies serves its own corporate purpose, we share a fundamental commitment to all of our stakeholders." How corporations intend to meet this commitment is unclear and becomes the focus of this paper.

In the spring of 2020, following the death of George Floyd and the resurgence of the Black Lives Matter movement, corporate leaders across a mosaic of industries reaffirmed their solidarity with protesters, their commitment to diversity, and pledged to be more responsive to their employees and communities. ${ }^{6}$ While a few corporate leaders have resigned

(2018) ("Despite persistent criticism, the idea of shareholder primacy has been widely accepted."); Henry Hansmann \& Reinier Kraakman, The End of History for Corporate Law, 89 GEO. L.J. 439, 439 (2001)

("There is no longer any serious competitor to the view that corporate law should principally strive to increase long-term shareholder value. This emergent consensus has already profoundly affected corporate governance practices throughout the world. It is only a matter of time before its influence is felt in the reform of corporate law as well").

4. Michael Siebecker, Making Corporations More Humane Through Artificial Intelligence, 45 IOWA J. CORP. L. 95 (2019)

("In August 2019, the Business Roundtable published an open letter (signed by nearly 200 corporate executives) that argued corporations must look beyond maximizing shareholder wealth and promote the interests of employees, suppliers, customers, the environment, and other stakeholders within communities the corporations inhabit. As The New York Times reported, the letter represented a significant departure from "decades of long-held business orthodoxy.")

(citing David Gelles \& David Yaffe-Bellany, Shareholder Value Is No Longer Everything, Top C.E.O.s Say, N.Y. Times (Aug. 19, 2019), https://www.nytimes.com/2019/08/19/busin ess/business-roundtable-ceos-corporations.html [https://perma.cc/FV5N-92Q2]).

5. Business Roundtable Redefines the Purpose of a Corporation to Promote 'An Economy That Serves All Americans' (Aug. 19, 2019), https://www.businessroundtable.o $\mathrm{rg}$ /business-roundtable-redefines-the-purpose-of-a-corporation-to-promote-an-economy-th at-serves-all-americans [https://perma.cc/UZX5-CJV5].

6. Pamela Newkirk, Corporations Say 'Black Lives Matter.' Here's What They Need to Do to Show They Mean It, TIME (June 25, 2020), https://time.com/5859213/corporationsblack-lives-matter [https://perma.cc/6FCN-ENH9]; Greg Bensinger, Corporate America Says Black Lives Matter, It Needs to Hold Up a Mirror, N.Y. Times (June 15, 2020), https://ww w.nytimes.com/2020/06/15/opinion/black-lives-matter-corporate-pledges.html [https://perm a.cc/QSN4-FJGD]; Tracy Jan et al., As Big Corporations Say 'Black Lives Matter,' Their Track Records Raise Skepticism, WASH. Post (June 13, 2020), https://www.w 
to free up executive positions to help diversify corporate leadership, ${ }^{7}$ and others have been forced out after tone-deaf media appearances or committing a racial faux-pas, ${ }^{8}$ changes in leadership are not nearly enough to address the demands of employees, investors, or the public.

If corporate governance is going to respond to demands to rethink the inclusivity of corporate behavior, and substantially and regularly deviate from the shareholder primacy model which has prevailed for more than a century, then the law must develop new tools to guide corporate boards. The law has tried. Over several decades, reporting on ESG metrics (Environmental, Social, Governance) has emerged to both help shareholders better understand the firms they invest in and to focus minds in the C-suite on important metrics beyond the bottom line. ${ }^{9}$ Investors use these reports to make investment decisions, but they appear to have had little effect on corporate leadership; in 2020 only four CEO's of the Fortune 500 companies were Black, and none were Indigenous. ${ }^{10}$

The law has also tried experimenting with the corporate form. In 2007 the first B-Corps (Benefit Corporations) were formally certified. ${ }^{11}$ These forprofit entities agreed to have themselves measured by their social and

ashingtonpost.com/business/2020/06/13/after-years-marginalizing-black-employees-custom ers-corporate-america-says-black-lives-matter/?arc404=true [https://perma.cc/2RE4-XXJ9].

7. Jemima McEvoy, Every CEO and Leader that Stepped Down Since Black Lives Matter Protests Began, FoRBES (July 1, 2020), https://www.forbes.com/sites/jemimamcevoy/ 2020/07/01/every-ceo-and-leader-that-stepped-down-since-black-lives-matter-protests-bega n/\#f16d4905593c [https://perma.cc/RP4J-VBED] (noting that Alexis Ohanian was the "first high-profile leader" to leave a corporate position. Ohanian from Reddit's Board after serving for more than fifteen years "pledging his seat on the otherwise all-white executive board to a Black candidate.").

8. Id. (documenting many cases of corporate leaders who have resigned after making racist or offensive comments including CrossFit CEO Greg Glassman, Second City CEO and co-owner Andrew Alexander, and Editor-in-Chief of Bon Appetit Adam Rapoport).

9. See generally Andy Green, Making Capital Markets Work for Workers, Investors, and the Public: ESG Disclosure and Corporate Long-Termism, 69 CASE W. RSRV. L. REV. 909 (2019); Susan Gary, Best Interests in the Long Term: Fiduciary Duties and ESG Integration, 90 U. Colo. L. Rev. 733 (2019); Max M. Schanzenbach \& Robert H. Sitkoff, Reconciling Fiduciary Duty and Social Conscience: The Law and Economics of ESG Investing by a Trustee, 72 STAN. L. REV. 381 (2020).

10. David Gelles, Corporate America has Failed Black America, N.Y. TIMES (June 6, 2020), https:/www.nytimes.com/2020/06/06/business/corporate-america-has-failed-blackamerica.html [https://perma.cc/F6MW-8VN2] ("In total, there are just four black chief executives among the 500 largest companies in the country.").

11. Jacob E. Hasler, Note, Contracting for Good: How Benefit Corporations Empower Investors and Redefine Shareholder Value, 100 VA. L. REV. 1279, 1283 n.26 (2014) ("B Corp certifications began in 2007 , three years before the first benefit corporation statute was passed"). 
environmental performance in addition to their earnings ratios. ${ }^{12}$ Investors were aware that returns may be slightly smaller given that the firm was being run with social objectives in mind, but the emergence of B-Corps have failed to substantially improve corporate governance generally. ${ }^{13}$ Benefit Corporations are still profit seeking, and their leadership is subject to removal by shareholders for poor financial performance. ${ }^{14}$ Moreover, BCorps are disproportionally set up in industries which are preternaturally disposed to be more environmentally friendly or socially progressive (i.e. renewable energy or materials science) and so have had little impact on encouraging other firms to move in a similar direction. ${ }^{15}$

12. Id. at 1284

("One goal of the certification was for it to become 'a sort of Moody's for social and environmental effect,' thereby 'unlocking a whole new source of capital.' The idea was that investors would look to the B Corp logo and businesses' impact scores when deciding whether to invest in these companies.").

See also Carol Liao, A Critical Canadian Perspective on the Benefit Corporation, 40 Seattle U. L. REV. 683 (2017) ("The benefit corporation aims to address the needs of social purpose businesses operating in the for-profit sector by requiring a "public benefit" purpose, among other governing features."); Justin Blount \& Kwabena Offei-Danso, The Benefit Corporation: A Questionable Solution to a Non-Existent Problem, 44 St. MARY's L. J. 617, 645 (2013) ("The shareholders essentially contract to require the benefit corporation to replace the goal of maximizing shareholder wealth with the goal of pursuing or creating a general public benefit.").

13. Steven Munch, Improving the Benefit Corporation: How Traditional Governance Mechanisms Can Enhance the Innovative New Business Form, 7 Nw. J. L. \& Soc. PoL'Y 170, 188 (2012)

("the real disadvantage of the benefit corporation may be that it does not do enough. This new form has yet to endure tests in practical use or challenges in legal suits. But as currently conceived, it lacks the kind of governance devices and procedures ... that could better facilitate its dual-mission success. While the benefit corporation legislation to date provides a strong, basic framework for social enterprise, it may not do enough to encourage mission fulfillment, to guide directors and officers, or to assist prospective investors.")

14. William H. Clark, Jr. \& Elizabeth K. Babson, When 'Business Purpose' Disappears: How Benefit Corporations are Redefining the Purpose of Business Corporations, 38 WM. MitCHELL L. REV. 817, 831-32 ("Without clear authority explicitly permitting directors to pursue both profit and a company's mission, even directors of mission-driven companies in constituency statute jurisdictions may be hesitant to "consider" their missions for fear of a fiduciary duty breach.").

15. Mark Loewenstein, Benefit Corporation Law, 85 U. CIN. L. Rev. 381, 384-85 (2017) (discussing the limitations of using the Benefit Corporation form;

"if a corporation is formed to achieve one or more of the goals, say promoting the advancement of knowledge, it cannot use the benefit corporation provisions unless it also has as a purpose of creating a material positive impact on society and the environment. It may be the organizers determine that they cannot achieve 
The disparity between these alternative management objectives and traditional conceptions of shareholder primacy has created the need for alternative perspectives on corporate governance. Small and incremental changes will not result in the rethinking of corporate behavior increasingly demanded by society. Corporate governance has been so deeply and firmly wedded to shareholder primacy that no radical reimagination of the corporate form has taken hold. Instead scholars suggest ever stricter reporting requirements, ${ }^{16}$ higher minimum wages and more stringent labor laws, ${ }^{17}$ or liability shields for corporations pursuing altruistic objectives. ${ }^{18}$ Others suggest that corporate behavior is beyond reform and that rather than expect profit seeking entities to change their behavior, governments could better respond to stakeholders by creating universal basic income schemes ${ }^{19}$ and/or by implementing more robust environmental and labor regulations with which all firms, regardless of their governance objectives, would be forced to comply. ${ }^{20}$

This article offers a different way forward. It looks to the Indigenous models of corporate governance for ideas on how to radically rethink both the structure of a corporation and corporate governance. By focusing on

both the general public benefit and the specific public benefit in which they have a particular interest. They therefore must forgo the benefit corporation label.").

16. David Case, Corporate Environmental Reporting as Informational Regulation: A Law and Economics Perspective, 76 U. CoLO. L. REV. 379 (2005).

17. Kent Greenfield, Governance, Accountability, and the Future of Corporate Law, 37 SEATtLE U. L. REV. 749 (2014) (comparing increases in the minimum wage with a stakeholder focused corporate governance system); Martin Gelter, The Dark Side of Shareholder Influence: Managerial Autonomy and Stakeholder Orientation in Comparative Corporate Governance, 50 HARV. INT'L L.J. 129, 173-176 (2009) (arguing for the need for greater labor protections because traditional models of corporate governance in the United States leave workers insufficiently unprotected).

18. Abir Ahmed \& Dezso Farkas, A Proposal to Encourage Up-The-Ladder Reporting by Insulating In-House Corporate Attorneys from Managerial Power, 39 DEL. J. CORP. L. 861 (2015) (discussing how shielding corporate counsel would encourage reporting and compliance).

19. Cynthia Estlund, What Should We Do After Work? Automation and Employment Law, 128 YALE L.J. 254, 290-92 (2018) (discussing how corporations acting rationally can avoid billions in compliance and labor costs by automating positions, and suggesting programs like universal health care and income support (through a universal basic income or a negative income tax) could be used to redress the problem).

20. Daniel J. Fiorino, Rethinking Environmental Regulation: Perspectives on Law and Governance, 23 HARV. ENVTL. L. REV. 441, 448 (1999) (arguing that changes in regulation and mandatory reporting are more effective means of changing corporate behavior. "Policy instruments based on reflexive legal rationality have become more common in the United States and elsewhere. The principal example is the growing use of information disclosure as a policy instrument. Many countries now are requiring firms to release information on their environmental performance to communities and other interested stakeholders."). 
Indigenous themes of equality, inclusivity, respect, and sustainability it suggests that corporations can be retooled to serve ESG objectives without unduly sacrificing the need to turn to a profit. Concrete suggestions are made to modify a corporation's time horizon to eliminate short-termism, to change the nature of voting rights to ensure greater accountability to stakeholders and sustainability objectives, and altering ownership rules to prevent the monopolization of decision making.

To make these arguments this paper first reviews the traditional model of corporate governance to understand what shareholder primacy is and why it has such an intractable hold on governance today. Part II briefly documents the movement against shareholder primacy and the need for an alternative. Part III then introduces the reader to tribal corporations. While in many law review articles this background section serves only to ground the scholar's argument in well-known and well-established legal principles, I have found that most governance scholars have virtually no knowledge of Indigenous corporations. This section is thus fundamentally important to create a baseline of knowledge upon which a dialog between Indigenous law scholars and corporate law/corporate governance scholars can be built. Part IV then walks through three observations which make Indigenous corporations different. It provides examples of Indigenous governance and makes some cross-application to how these principles might be incorporated into modern corporate law. It calls for three notable changes; (1) a movement away from the incentives for short-termism in corporate governance, (2) changes in the voting rights of corporate shares, and (3) alterations to ownership rules - reimagining both who can own shares and limiting the ability for a minority of shareholders to subvert the interests of all corporate stakeholders. Finally, Part V provides some short concluding observations and encourages corporations and corporate law scholars to engage more deeply and readily with their Indigenous law counterparts.

\section{The Traditional MOdEL OF CORPORATE GOVERNANCE}

The traditional model of corporate governance is premised on shareholder primacy. Essentially shareholder primacy dictates that managers run a corporation for the benefit of the shareholders. ${ }^{21}$ Shareholders, as owners of the corporation, have a claim to a pro-rata share of the profits. The shareholders elect the Board which is responsible for the hiring and firing of the $\mathrm{CEO}$ and which provides assistance assessing risk

21. See Rhee, supra note 3, at 1952 (discussing how the Board must manage the company for the purpose of maximizing shareholder wealth). 
and advising management on investment strategy and direction. Managers, in turn, are incentivized to make decisions to maximize the profit of the corporation which directly enriches the shareholders. If the shareholders are unhappy with the corporation's direction, they may exercise their rights to elect different persons to the Board. The Board may then exercise its oversight function and replace the $\mathrm{CEO}$ and/or provide different assessments and advice to corporate management thereby altering the corporation's direction. ${ }^{22}$

An astute observer should have no trouble seeing the difficulties of responding to social or environmental concerns under the shareholder primacy model. If corporate management suggests paying living wages when they are able to staff their positions for less, or if the costs of being a good environmental steward exceed the costs of basic compliance with environmental rules, then corporate decision makers who agree to take on these additional costs as socially responsible actors risk attracting the ire of shareholders whose profits are correspondingly diminished. ${ }^{23}$ In order to protect their jobs, managers of publicly traded firms are incentivized under this model to avoid implementing costly but socially or environmentally desirable policies like paying living wages or adopting carbon reduction strategies. ${ }^{24}$

Inarguably there are instances where being socially responsible is also good for a corporation's profitability. A corporation may pay higher wages to reduce the costs associated with turnover like hiring and retraining new workers, or to avoid the loss of institutional memory. A goods manufacturer may redesign its packaging to use less material, to take up less space, and/or to weigh less and in so doing reduce the cost of shipping its products while correspondingly generating less waste and saving fuel. A warehouse or corporate headquarters may add solar panels to a roof or parking structure to defray utility costs. These socially conscious and environmentally friendly

22. See generally James P. Holdcroft, Jr. and Jonathan R. Macey, Corporate Governance Flexibility in Determining the Role of the Board of Directors in the Age of Information, 19 CARDOZO L. REV. 291 (1997) (arguing for a corporate governance structure where shareholders, in part, can direct boards to replace poorly performing managers).

23. Carol Liao, Corporate Governance Reform for the 21st Century: A Critical Reassessment of the Shareholder Primacy Model, 43 Oтташа L. Rev. 187, 191 (2013). While ultimately critiquing the model, Prof. Liao first provides an excellent summary of the basics of shareholder primacy including that managers have an obligation to manage the corporation for the benefit of shareholders and that other constituencies, like employees, customers, society etc., have their interests protected not by corporate management but by other means like contract or governmental regulation.

24. See Estlund, supra note 19, at 290-294 (making this exact point about how employees and labor laws add additional costs and liabilities to corporate bottom lines which incentivizes automation). 
hypotheticals are perfectly consistent with shareholder primacy because they make the firm more profitable. However where the tradeoffs impose higher costs on the corporation for being a greener or more socially conscious corporate entity, the shareholder primacy model suggests that managers have a legal obligation to prefer the interests of their shareholders and to cut costs at the expense of other social goods like paying living wages or promoting environmental sustainability. ${ }^{25}$ Corporate profits get a judicial thumb on the scale when being weighed against other costly but socially desirous policies.

\section{A. The Origins of Shareholder Primacy}

So where did Shareholder Primacy come from and how did it become the presumptive model of corporate governance? While many scholars ${ }^{26}$ trace the academic origin of shareholder primacy to Adolf Berle's classic Corporate Powers as Powers in Trust, ${ }^{27}$ the courts have predated the robust theoretical explanation articulated by Berle by more than a decade. In 1919 the Supreme Court of Michigan articulated the role of the corporate manager and the power of the shareholder in the classic case of Dodge v. Ford Motor Company:

A business corporation is organized and carried on primarily for the profit of the stockholders. The powers of the directors are to be employed for that end. The discretion of directors is to be exercised in the choice of means to attain that end, and does not extend to a change in the end itself, to the reduction of profits, or to the non-distribution of profits among stockholders in order to devote them to other purposes. ${ }^{28}$

The Dodge opinion has become among the most canonical of corporate governance cases. ${ }^{29}$ It reasons that while managers have some discretion in

25. See Liao, supra note 23.

26. See generally William Bratton and Michael Wachter, Shareholder Primacy's Corporatist Origins: Adolf Berle and The Modern Corporation, 34 IOwA J. CORP. L. 99 (2008) (discussing the contested origins of shareholder primacy).

27. Adolf A. Berle, Corporate Powers as Powers in Trust, 44 Harv. L. Rev. 1049 (1931).

28. Dodge v. Ford Motor Co., 204 Mich. 459, 507 (1919).

29. See generally Dalia Mitchell, From Dodge to Ebay: The Elusive Corporate Purpose, 13 VA. L. \& Bus. REv. 155 (2019) (recognizing Dodge as one of the most famous corporate cases which draws attention to corporate purpose); Alan Weinberger, Henry Ford's Wingman: A Perspective on the Centennial of Dodge v. Ford, 14 N.Y.U. J.L. \& Bus. 1013 (2014) (noting how Dodge has pointed to important corporate law developments such as the business judgment rule and fiduciary duties of majority shareholders); Marina Welker, Notes on the Difficulty of Studying the Corporation, 39 Seattle U. L. Rev. 397 (2016) (calling Dodge one of two conventional touchstones in U.S. corporate law that defines corporate purpose as 
making decisions on how to grow a corporation, they may not abandon the ultimate goal of profit maximization and protection of shareholder value by substituting other humanitarian or beneficent ends even when those goals may be generally socially desirous.

The Dodge case arose after the Ford Motor Company had become very profitable but was sitting on large amounts of cash instead of distributing those holdings to its investors as dividends. ${ }^{30}$ Dodge, a minority shareholder, sued in order to force Ford to distribute more of its accumulated capital. Henry Ford, the largest shareholder, had made clear through his counsel that he opposed distributing more of the company's cash holdings to investors as dividends, suggesting instead that the money might be employed for other purposes: "Although a manufacturing corporation cannot engage in humanitarian works as its principal business, the fact that it is organized for profit does not prevent the existence of implied powers to carry on with humanitarian motives such charitable works as are incidental to the main business of the corporation." ${ }^{31}$ In articulating the basic premise behind shareholder primacy, the Supreme Court of Michigan ordered that Ford Motor Company distribute more of its capital: "[I]t is not within the lawful powers of a board of directors to shape and conduct the affairs of a corporation for the merely incidental benefit of shareholders and for the primary purpose of benefiting others ...."32 Shareholder primacy has emerged as the natural outgrowth of that legal premise.

Dodge dealt a blow to one of the most profitable American corporations controlled by an icon of American manufacturing. The Court's affirmation of the rights of minority shareholders created a baseline by which shareholders could use the law to prevent corporate managers and corporate boards from repurposing the profits of a corporation toward humanitarian, social, or environmental ends. ${ }^{33}$ Dodge, and the doctrine of shareholder

maximizing profits); Lynn Stout, Why We Should Stop Teaching Dodge v. Ford, 3 VA. L. \& Bus. REV. 163 (2008) (arguing that while Dodge has been widely cited for proposition of corporate purpose is maximizing shareholder wealth, the decision is bad law); and Anupam Chander, Minorities, Shareholder and Otherwise, 113 YALE L.J. 119 (2003) (describing the case as "canonical" although critiquing some scholars' interpretation of its holding).

30. Dodge v. Ford Motor Co., 204 Mich. 459, 505 (1919).

31. Id. at 506 .

32. Id. at 507. See also id. at 502 ("After the business of a corporation has been brought to a prosperous condition, and necessary provision has been made for future prosperity, a reasonable share of the profits should be applied in the payment of regular dividends ...").

33. For example, in Dodge, Ford explained that he wished to continue to expand the business and provide high paying jobs for as many employees as possible even at the expense of some profitability:

“"My ambition,' said Mr. Ford, 'is to employ still more men, to spread the 
primacy it helped usher in, has served as a barrier to corporate social responsibility for more than a century. As Professors Henry Hansmann (Yale) and Reiner Kraakman (Harvard) observed, "there is today a broad normative consensus that shareholders alone are the parties to whom corporate managers should be accountable, resulting from widespread disenchantment with a privileged role for managers, employees, or the state in corporate affairs." 34

\section{B. The Intervening Role of the Business Judgment Rule}

A discussion of shareholder primacy, even briefly, would be incomplete without recognizing the role of the business judgment rule. As the Delaware Supreme Court explains, the business judgment rule is a " "presumption that in making a business decision the directors of a corporation acted on an informed basis, in good faith and in the honest belief that the action taken was in the best interests of the company." "35 It can serve as a defense for corporate management in a shareholder initiated suit, placing the burden of showing a management decision was improper on the shareholder challenging the corporation's governance and requiring that the challenger overcome the presumption that any management decision was made in the corporation's best interest. ${ }^{36}$ For example, while a corporation's Board may

benefits of this industrial system to the greatest possible number, to help them build up their lives and their homes. To do this we are putting the greatest share of our profits back in the business."”

Id. at 505. The Michigan Supreme Court reasoned that it was improper for a corporation to privilege higher wages or lower profits over a return of capital to shareholders: "There should be no confusion (of which there is evidence) of the duties which Mr. Ford conceives that he and the stockholders owe to the general public and the duties which in law he and his codirectors owe to protesting, minority stockholders." Id. at 507.

34. Henry Hansmann and Reinier Kraakman, The End of History for Corporate Law, 89 GEO. L.J. 439, 441 (2001).

35. Omnicare, Inc. v. NCS Healthcare, Inc., 818 A.2d 914 (Del. 2003) (citing Aronson v. Lewis, 473 A.2d 805, 812 (Del. 1984)). See generally Leo Strine Jr., Lawrence Hamermesh, R. Franklin Balott, and Jeffrey Gorris, Loyalty's Core Demand: The Defining Role of Good Faith in Corporation Law, 98 GEO. L.J. 629 (2010) (including the business judgment rule in discussion over duty of loyalty and concept of good faith); Lawrence E. Mitchell, Fairness and Trust in Corporate Law, 43 DuKE L.J. 425 (1993) (discussing how courts will apply the business judgment rule when evaluating shareholder challenges to fiduciaries' actions); and Alan R. Palmiter, Reshaping the Corporate Fiduciary Model: A Director's Duty of Independence, 67 TEX. L. REV. 1351 (1989) (considering the business judgment rule in the context of promoting a duty of independence).

36. See Ann M. Scarlett, Confusion and Unpredictability in Shareholder Derivative Litigation: The Delaware Courts' Response to Recent Corporate Scandals, 60 FLA. L. REV. 589, 594 (2008) ("The business judgment rule supplies the pivotal defense for corporations 
make charitable contributions which, by their very nature, reduce the pool of money to be reinvested in the business or distributed to shareholders, Delaware courts have held that "reasonable" contributions are allowed and "that not every charitable gift constitutes a valid corporate action."37

The Michigan Supreme Court in Dodge reconciled shareholder primacy with the business judgment rule. It reasoned that:

The managing agents of a corporation are impliedly invested with a discretionary power with regard to the time and manner of distributing its profits. They may apply profits in payment of floating or funded debts, or in development of the company's business; and so long as they do not abuse their discretionary powers, or violate the company's charter, the courts cannot interfere. $^{38}$

However, it is notable that the discretion afforded management is of the time, place, or manner of the distribution of profits or reinvestment of proceeds. Dodge is nonetheless clear that while management is afforded wide discretion on how the business is run, it may not reappropriate the profits of the corporation for humanitarian ends at the expense of the shareholders' claim to the proceeds:

[I]t is clear that the agents of a corporation, and even the majority, cannot arbitrarily withhold profits earned by the company, or apply them to any use which is not authorized by the company's charter. ... If a majority of the shareholders or the directors of a corporation wrongfully refuse to declare a dividend and distribute profits earned by the company, any shareholder feeling aggrieved may obtain relief in a court of equity. ${ }^{39}$

Under the doctrine of shareholder primacy there are limits to the discretion the business judgment rule provides, and these limits create strong disincentives to afford stakeholders a greater say in corporate governance.

and directors in derivative litigation, and the defendant-directors may assert the defense both in pretrial motions and at trial. If a plaintiff cannot overcome the defense, the case ends").

37. Kahn v. Sullivan, 594 A.2d 48, 60-61 (Del. 1991).

38. Dodge v. Ford Motor Co., 204 Mich. 459, 501 (1919).

39. Id. See also Tower Hill-Connellsville Coke Co. v. Piedmont Coal Co., 64 F.2d 817 (4th Cir. 1933) (applying this principle to permit minority shareholders to recover against majority shareholders, and even permitting the court to wind up the corporation as a remedy for gross abuse of trust). 


\section{THE NEED TO RETHINK SHAREHOLDER PRIMACY}

In their article The End of History for Corporate Law $^{40}$ Professors Hansmann and Kraakman argue that in the twenty-first century there will emerge a consensus around the principle of shareholder primary, and that its inherent logic and alignment of incentives and values will solidify the doctrine to withstand challenges from any competing theory of corporate law:

$[\mathrm{N}]$ ow, as a consequence of both logic and experience, there is convergence on a consensus that the best means to this end (that is, the pursuit of aggregate social welfare) is to make corporate managers strongly accountable to shareholder interests and, at least in direct terms, only to those interests. ${ }^{41}$

From their vantage point in 2001 - after a decade of unprecedented economic growth, record low unemployment, and the emergence of the United States with unrivaled levels of hard and soft power, there was a clear path forward for the untrammeled rights of the shareholder. While recognizing that there were voices calling for a greater role for stakeholders in corporate governance (employees, members of the local community, and even groups like "beneficiaries of a well-preserved environment" ${ }^{\text {"42 }}$ ), Professors Hansmann and Kraakman believed that corporate law would not allow these non-shareholder groups greater control because doing so would be inefficient. They explained: "The mandatory inclusion of any set of stakeholder representatives on the board is likely to impair corporate decision-making processes with costly consequences that outweigh any gains to the groups that obtain representation.,"43 A growing number of scholars, stakeholders, and even shareholders now disagree.

Scholars routinely suggest that to protect ourselves and future generations, corporations must become more sustainable: ““[B]usiness as usual' is not viable if we wish to preserve the very basis of our existence." "44 The shareholder primacy model is largely antithetical to societal efforts to promote sustainability because the additional costs imposed on corporations

40. Henry Hansmann and Reinier Kraakman, The End of History for Corporate Law, 89 GEO. L.J. 439 (2001).

41. Id. at 441 .

42. Id. at 447 .

43. Id. at 448-49.

44. Beate Sjåfjell, Andrew Johnston, Linn Anker-Sørensen, and David Millon, Shareholder Primacy: The Main Barrier to Sustainable Companies in COMPANY LAW AND Sustainability: Legal Barriers and Opportunities 79 (Beate Sjåfjell \& Benjamin J. Richardson eds., 2015). 
to improve environmental protection/compliance and correct the negative externalities of corporate behavior impose costs on management which trade off with providing shareholder returns. ${ }^{45}$ Unless required by enhanced regulation managers will make corporate decisions to reduce or avoid costs at the expense of paying living wages or addressing social concerns about environmental preservation. With rising levels of inequality and excessive executive compensation, ${ }^{46}$ advocates for giving stakeholders an enhanced role in corporate governance include coalitions with interests beyond environmental concerns. ${ }^{47}$ Society is increasingly demanding that corporations pay living wages and care for the communities in which they are situated at least as much as they care for shareholders. ${ }^{48}$ The demand for corporations to respond to, and protect, the interests of their broader stakeholders are squarely in conflict with traditional conceptions of shareholder primacy. ${ }^{49}$

45. See Benedict Sheehy, Conceptual and Institutional Interfaces Between CSR, Corporate Law and the Problem of Social Costs, 12 VA. L. \& BuS. Rev. 93, 141 at n. 254 ("Shareholder primacy itself is a major obstacle to sustainability.").

46. Deb Lifshey, The CEO Pay Ratio: Data and Perspectives from the 2018 Proxy Season, HARV. L. SCH. F. ON CORP. Governance (Oct. 14, 2018), https://corpgov.law.ha rvard.edu/2018/10/14/the-ceo-pay-ratio-data-and-perspectives-from-the-2018-proxy-season/ [https://perma.cc/64JJ-FPKB]. In 2018, CEOs in the consumer discretionary section earned an average multiple of $384 \mathrm{x}$ the median employee salary while CEOs in the consumer staples section earned an average multiple of 295x median salary. Utility companies had the lowest ratio, with CEO compensation being set at an average of 58.5x median employee salary.

47. See Joel Slawotsky, The Virtues of Shareholder Value Driven Activism: Avoiding Governance Pitfalls, 12 HASTINGs Bus. L.J. 521, 546 (2016)

("Under the stakeholder model, where the company is considered as a nexus of 'unwritten' contracts between various constituencies of the business who may have an interest in it, it is the contract which determines the rights and obligations of the various stakeholders. In terms of corporate governance and company law, directors are to make decisions that take into account the interests of these various 'constituents' who are considered as having 'rights' in the company. These stakeholders in the business encompass a wide array of interests including: creditors, employees, suppliers, customers, the environment, and the community."

(footnote omitted)).

48. See Veronique Magnier and Darren Rosenblum, Quotas and the Transatlantic Divergence of Corporate Governance, 34 Nw. J. INT'L L. \& Bus. 249, 279 (2014) ("Managerial accountability constitutes another issue for stakeholder-oriented corporate governance. Unlike an executive with a well-defined mission to maximize shareholder value - viewed as an objective task - the socially-oriented manager faces a wide range of missions, most of which are, by nature, not entirely measurable." (footnote omitted)).

49. See Justin Blount, Creating a Stakeholder Democracy under Existing Corporate Law, 18 U. PA. J. Bus. L. 365, 371 (2016) ("[S]takeholder theory is often characterized as being opposed to the shareholder primacy model of the corporation, or at least opposed to a focus on shareholder wealth maximization as the proper objective of the corporation." (footnote 
While there is an increasing consensus on the need to change corporate governance to address the concerns of stakeholders and redesign corporate policy with sustainability at the forefront ${ }^{50}$ the world of corporate law has yet to coalesce on a way forward. The Benefit Corporation, while articulating socially conscious goals, is still subject to control by a few large majority shareholders who can challenge the decisions of the managerial class if returns prove to be insufficient. ${ }^{51}$ Moreover, different shareholders in a benefit corporation may have different ideas about the extent or purpose of the B-Corp and bring conflicting challenges to corporate leadership. ${ }^{52}$ Such a structure, while noble in its goal, is prone to infighting and structurally permits rogue shareholders to ultimately circumvent a benefit corporation's more munificent purpose. ${ }^{53}$

Additional reporting requirements, including a focus on ESG objectives (Environmental, Social, and Governance) may at the margins influence corporations to act differently because they have to report on their compliance - but ESG metrics have done little to change the motivations of the shareholder class beyond allowing firms to create new and more expensive financial products claiming to focus on green or sustainable investing. ${ }^{54}$ Firms appear to massage their compliance under the umbrella of risk management, doing just enough to promote environmental or social goods as is required to prevent themselves from being branded as uncooperative or uncaring - rationally allowing reform to consume only those resources necessary to avoid adverse reputational attention which

omitted)).

50. See Beate Sjåfjell and Christopher M. Bruner, The Cambridge Handbook of Corporate Law, Corporate Governance, and Sustainability, Cambridge U. Press (2020) (summarizing this emerging consensus in the United States and among corporate law scholars around the world).

51. See Justin Blount and Kwabena Offei-Danso, The Benefit Corporation: A Questionable Solution to a Non-Existent Problem, 44 St. Mary's L. J. 617, 645 (2013) (“'J]ust like in a business corporation, shareholders maintain control through their voting power").

52. Id.

("For any given scenario, given the broad discretion afforded directors and officers of the benefit corporation, it is entirely possible that multiple shareholders could bring benefit enforcement proceedings advocating for conflicting positions which they perceive as being in the general public benefit. How would a judge decide such a case?").

53. $I d$.

54. See Federico Fornasari, Knowledge and Power in Measuring the Sustainable Corporation: Stock Exchanges as Regulators of ESG Factors Disclosure, 19 Wash. U. Global Stud. L. Rev. 167, 170 (2020) ("[I]t is widely assessed that the existing voluntary reporting schemes fail in providing investors with decision-useful information."). 
might cost more than compliance itself. ${ }^{55}$ CSR, or Corporate Social Responsibility, has been bandied about now for almost three decades as a panacea which will help reform corporate institutions ${ }^{56}$ but it has failed to bring about substantial changes to corporate structure or behavior. ${ }^{57}$ Clearly reporting alone is insufficient to break the bonds between shareholder primacy and corporate governance. Something more is needed to usher in an era of stakeholder focused corporate sustainability.

It is against this backdrop that this paper offers the lessons that can be drawn from Indigenous corporate governance. By leaving behind the preconceived notions and principles of corporate law long codified in both common and civil legal traditions, and embracing instead the ideals embodied in autochthonous law, new ideas for the reform of corporate law emerge.

\section{INDIGENOUS CORPORATIONS}

The central thesis of this article is that Indigenous corporations and chthonic or autochthonous legal principles ${ }^{58}$ can provide a radically different way to conceptualize the corporation and the relationship between management and shareholders. We should look to these Indigenous corporate models in order to refine traditional corporate governance. By imbedding the lessons of Indigenous governance into corporate law we can create corporate entities which are run sustainably, and which respond to social, environmental, and community concerns while still generally providing profitable returns to be distributed to shareholders.

55. Id. ("The 'doing good while doing well' approach has been partially substituted by business risk considerations").

56. See Benedict Sheehy, Conceptual and Institutional Interfaces Between CSR, Corporate Law and the Problem of Social Costs, 12 Va. L. \& Bus. Rev. 93, 95 (2017) ("CSR is seen as an answer to a wide array of issues associated with the corporate form.").

57. See Antony Page and Robert A. Katz, Is Social Enterprise the New Corporate Social Responsibility?, 34 Seattle U. L. Rev. 1351, 1361 (2011) ("Thus, although CSR may have good ideas about corporate behavior, it has generally failed to produce meaningful large-scale legal reform."). See also Faith Stevelman, Globalization and Corporate Social Responsibility: Challenges for the Academy, Future Lawyers, and Corporate Law, 53 N.Y. L. Sch. L. Rev. 817,833 (2008) ("[C]ritics of CSR cannot, in good faith, counter that a corporation's job is merely to conform to the existing regulations, because it is apparent that regulations and regulators cannot keep up with corporations determined to outrun them."). 2014).

58. See H.P. Glenn, Legal Traditions of the World 60-94 (Oxford U. Press, 5th ed. 
Indigenous communities are sovereign. ${ }^{59}$ Federal law permits Indian $^{60}$ tribes to create corporations which share in the sovereignty of the tribal government. ${ }^{61}$ Most Native Alaskan communities were organized as corporations in $1971^{62}$ and Alaska Native Corporations have experimented with corporate governance beyond anything imaged by B-Corps or L3C entities. Tribes may also adopt corporate codes permitting others to create corporations under tribal law. ${ }^{63}$ Tribal law may have its own regulatory and compliance schemes that are free to differ substantially from corporate forms chartered under state law. Indigenous communities outside of the United States have also experimented with reimagining the structure and purpose of a corporation and what it means to "own" shares. Together all of these Indigenous corporate entities operate with wide latitude inside traditional governance principles but are ultimately subject to autochthonic law created and enforced by the Indigenous sovereigns through which they are chartered.

\section{A. Chthonic or Autochthonous Law}

Tribal governments, and their concomitant sovereign powers, were not initially expressed through formal writings. As Cohen's Handbook of Federal Indian Law notes; "In precontact times, different worldviews and experiences molded Indian nations into an array of evolving governmental

59. See Michigan v. Bay Mills Indian Community, 572 U.S. 782, 788 (2014) (citing Oklahoma Tax Comm'n v. Citizen Band Potawatomi Tribe of Okla., 498 U.S. 505, 509 (1991) that explains, "Indian tribes are 'domestic dependent nations' that exercise 'inherent sovereign authority." ). See also Worcester v. Georgia, 31 U.S. 515, 559 (1832) ("The Indian nations had always been considered as distinct, independent political communities, retaining their original natural rights, as the undisputed possessors of the soil, from time immemorial.").

60. See Federally Recognized Indian Tribes List Act of 1994, Pub. L. 103-454, 108 Stat. 4791 (1994) (explaining that the word "Indian" is a legal term of art and is regularly used in the law and by lawyers to describe many of America's Indigenous people. The term is used to codify the definition of 'Indian country' at 18 USC $\S 1151$ and is used to determine which tribes share in a government-to-government relationship). But see H.P. GLENN, LEGAL Traditions of the World 60-94 (Oxford U. Press, 5th ed. 2014) (discussing how the term 'Indian' is more problematic in an international context see H.P. Glenn, Legal Traditions of the World, 60 at n.1 (Oxford University Press, 5th ed., 2014)).

61. 25 U.S.C. $\S 5124$.

62. See generally Alaska Native Claims Settlement Act of 1971, Pub. L. No. 92-203, 85 Stat. 688 (Codified at 43 U.S.C. $\$ 1601$ et. seq.) (1971).

63. See Model Tribal Business Corporation Code (Bureau of Indian Aff.) (outlining regulations for tribally chartered corporations). See also WinNEBAGo Business CORPORATION CODE (outlining how individual tribes have also adopted their own codes pursuant to their inherent tribal sovereignty, which reflect their own internal processes and values without reference to state or federal law). 
forms. ${ }^{\circ 4}$ The origins of Indigenous law and governance are thus not written down in any definitive or canonical text; "[b]ecause precontact tribal governments were not memorialized in written constitutions or statutes, information about these governments comes from the oral traditions of native peoples, anthropological studies of variable quality, and the sometimes unreliable written accounts of early non-Indian traders, missionaries, and military." ${ }^{95}$ Despite the comparative dearth of primary texts, Indigenous people $^{66}$ had no trouble constructing legal systems and norms to govern disputes among themselves and their neighbors. But how do we classify these legal traditions?

H.P. Glenn suggests that Indigenous legal thought belongs not to the common law or civil law, but to its own inherent legal tradition. ${ }^{67}$ In English the Indigenous legal tradition has come to be called "chthonic" or "autochthonous" ${ }^{68}$ from the Greek "chthon" meaning earth because the

64. See COHEN'S HANDBOOK OF FEDERAL INDIAN LAW 254 (Nell Jessup Newton ed., 2012).

65. Id. at n. 1 .

66. See José Martínez Cobo, Special Rapporteur of the Sub-Commission on Prevention of Discrimination and Protection of Minorities, Study of the Problem of Discrimination against Indigenous Populations, U.N. Doc. E/CN.4/ Sub.2/1986/7/Add. 4, para. 379 (1986) (explaining that there is no one standard definition or definitive list of all Indigenous groups. The most frequently cited definition of the groups that fall within the rubric of Indigenousness comes from the Special Rapporteur of the Sub-Commission on Prevention of Discrimination and Protection of Minorities, José Martínez Cobo:

"Indigenous communities, people and nations are those which, having a historical continuity with pre-invasion and pre-colonial societies that developed on their territories, consider themselves distinct from other sectors of the societies now prevailing on those territories, or parts of them. They form at present nondominant sectors of society and are determined to preserve, develop and transmit to future generations their ancestral territories, and their ethnic identity, as the basis of their continued existence as people, in accordance with their own cultural patterns, social institutions and legal systems."

This definition tries to identify the characteristics of an Indigenous group without attempting to provide a definitive list of groups that are entitled to claim Indigenousness or expressly excluding any group from the Indigenous community. The Special Rapporteur's definition is explicit that among the attributes shared by Indigenous peoples are a determination to "preserve" their territories. Such preservation is not bounded by time, and the development of Indigenous legal principles stem from an inherent notion that the law is created and understood with full regard of its potential effects and consequences on ancestors, the present community, and the future).

67. See H.P. Glenn, Legal Traditions of the World 60-94 (Oxford U. Press, 5th ed. 2014) (discussing the history of Indian legal thought).

68. I use these two terms interchangeable throughout this piece. While chthonic is the term used most readily by Glenn, other scholars prefer the term autochthonous because of how the term chthonic has become associated in English not just with the earth but with the 
origin of the law has developed from the people where they have always lived. ${ }^{69}$ Glenn describes autochthonous law as the original legal tradition; "[s]ince all people of the earth are descended from people who were chthonic, all other traditions have emerged in contrast to chthonic tradition." ${ }^{, 70}$ Autochthonous law finds its origins in tradition, custom, practice, and teaching. ${ }^{71}$ It has been preserved and passed down orally through generations and has manifested itself through stories and ceremonies. $^{72}$

One of the most important aspects of autochthonous law is that because it is not written down there is no one person who can claim a monopoly on legal knowledge. "The law is vested in a repository in which all, or most, share and in which all, or most, may participate."73 Chthonic law must therefore be explicatory to the general public and no party may use twisted convolutions of language in order to escape judgment or avoid penalty when their conduct makes them a bad actor; "the tradition faces less danger of pecuniary and institutional corruption, offering fewer positions of prestige and authority." 74

While Indigenous legal traditions may not have originally developed corporate law (principles like limited liability being anathema to a community based legal system), chthonic tradition does readily provide principles by which to govern corporations and institutions. In a system where the conduct of any constructed entity is judged by the entire community, the goals of the institution are not permitted to deviate materially from the best interest of society. The contours of this system thus have natural limiting principles ensuring that institutions (including corporations) may not inherently seek their own interests in ways that threaten or damage communal resources. Stewardship for the environment, egalitarian

underworld, and may carry negative connotations. Either term accurately conveys the idea of law coming from within, from original custom and practice, coming from the ground up. See Beate Sjåfjell and Christopher M. Bruner, The Cambridge Handbook of Corporate Law, Corporate Governance, and Sustainability, Cambridge U. Press (2020) (discussing Grant Christensen, What Does It Mean to Be Sustainable? Regulating the Relationship between Corporations and Indigenous).

69. GLENN, supra note 43, at 62.

70. GLENN, supra note 58, at 62 .

71. GLENN, supra note 59, at 62-64.

72. Id. See also Keith Basso, Wisdom Sits in Places: Landscape and Language Among the Western Apache (Univ. New Mexico Press, 1996) (providing an excellent anthropological take on the role of stories in forming autochthonous law). But see Robert Yazzie, Life Comes from It: Navajo Justice Concepts, 24 N.M. L. Rev. 175 (1994) (discussing how chthonic law plays a role in tribal governance today).

73. GLENN, supra note 59, at 64-65.

74. Id. at 65 . 
compensation schemes, and conservation of resources are all functionally required in an autochthonous legal order.

Elders play an important role in controlling institutions because in a legal system predicated upon ceremony and tradition they have the greatest institutional knowledge. Elders become "individual people who, by their assimilation of tradition over a longer period of time, often speak with greater authority." ${ }^{75}$ Institutions which challenge community norms or which attempt to set policy at odds with the interests of the group find themselves subject to scrutiny by elders (and other keepers of traditional knowledge) and are forced to change their behavior to conform with chthonic principles. This role of autochthonous law has greatly influenced the development of Indigenous corporations and will play a foundational role in the suggestions this article makes for reforming modern corporate governance.

H.P. Glenn was among the progenitors ${ }^{76}$ of this movement toward recognizing autochthonous legal traditions, but in the two decades since his work first appeared the contextualization of chthonic law has become mainstream. Law schools around the United States teach "Tribal Law" in addition to "Federal Indian Law"

75. Id.

76. His work is by no means the first or only articulation that Indigenous legal principles are rooted in oral tradition, custom, practice, stories, or ceremony. Indigenous peoples themselves have often made that point in the literature. See Robert Yazzie, 'Life Comes from It': Navajo Justice Concepts, 24 N.M. L. REV. 175 (1994) (contrasting Navajo law with Anglo law in regard to its Indigenous roots); Christine Zuni-Cruz, Tribal as Indigenous Social Reality and Separate Consciousness-ReIncorporating Customs and Traditions into Tribal Law, 1 TRIBAL L.J. 1 (2000) (describing how Najao laws are directly influenced by the people subjected to the law); Matthew L.M. Fletcher, Tribal Employment Separation: Tribal Law Enigma, Tribal Governance Paradox, and Tribal Court Conundrum, 38 U. Mich. J.L. Ref. 273 (2005) (outlining the differences between U.S. and tribal employment, namely, that tribal communities are close-knit and officials are especially held accountable); Matthew L.M. Fletcher, The Supreme Court's Legal Culture War against Tribal Law, 2 InTERCULTURAL Hum. RTs. L. REV. 93 (2007) (highlighting that tribal law is largely influenced upon oral tradition); Pat Sekaquaptewa, Key Concepts in the Finding, Definition and Consideration of Custom Law in Tribal Lawmaking, 32 AM. INDIAN L. REV. 319 (2008) (describing the vast differences between traditional U.S. law customs and tribal law); Raymond Austin, American Indian Customary Law in the Modern Courts of American Indian Nations, 11 Wyo. L. REV. 351 (2011) (stating the importance of culture, values, languages, and religion practices must be taken into account when attempting to revitalize tribal law).

77. Federal Indian Law is the student of the relationship between sovereigns: tribes, states, and the United States. Tribal Law is the study of the law of tribes themselves. The commonly assigned text is Matthew L.M. Fletcher, American Indian Tribal Law (Aspen, 2011). See Christine Zuni-Cruz, Tribal as Indigenous Social Reality and Separate Consciousness-ReIncorporating Customs and Traditions into Tribal Law, 1 TRIBAL L.J. 1 (2000) (describing the difference between Federal Indian law and Tribal law, and providing 
Columbia now offers a joint law degree in Canadian Common Law and Indigenous Law. ${ }^{78}$ Tribal law has arrived as a field in its own right. ${ }^{79}$ As tribal law becomes disseminated amongst a much wider legal audience it is a matter of when, not if, autochthonous legal thought begins to influence mainstream legal philosophy and jurisprudence. The body of Indian law scholarship has already increased almost ten-fold in the last thirty years. ${ }^{80}$

Indigenous and non-Indigenous scholars alike have built upon the role of autochthonous law to explore its application in a variety of contexts. Christine Zuni Cruz suggests that tribal judges who speak Indigenous languages are a critical conduit between the implementation of autochthonous law that has not been written down and the socio-legal principles which flow from oral tradition; "[ $\mathrm{t}]$ o some extent the gap between the written law and the societal norms of 'the People' can be bridged by the judge, something at which tribal court judges who are tribal members and fluent in the tribal language can be particularly effective." 81 A former Chief Justice of the Navajo Nation's Supreme Court talks about what justice looks like when artifice does not interfere with the goal of justice as healing;

[i]magine a system of law which permits anyone to say anything during the course of a dispute. A system in which no authority figure has to determine what is "true". Think of a system with an end goal of restorative justice which uses equality and the full participation of disputants in a final decision. If we say of law that "life comes from it," then where there is hurt, there must be healing." 82

additional context to the sources of tribal law; "At some point in my legal career, I recall becoming increasingly uncomfortable with the inconsistencies between the values in the written law of various indigenous nations and the values I knew were embedded in indigenous societies themselves. The two are not entirely in harmony, and in fact, in some instances are absolutely in opposition").

78. Joint Degree Program in Canadian Common Law and Indigenous Legal ORDERS, https://www.uvic.ca/law/about/indigenous/jid/index.php [https://perma.cc/R8UTG5GZ].

79. For an excellent discussion of the emergence of Indian law and tribal law in American law schools see Melissa Tatum, Symposium: Native American Law: Forward, 37 Tulsa L. REV. 481 (2001).

80. See Grant Christensen and Melissa Tatum, Reading Indian Law: Evaluating Thirty Years of Indian Law Scholarship, 54 TULSA L. REV. 81 (2018) (describing the almost exponential growth in Indian law legal scholarship over the period from 1985-2015).

81. Christine Zuni-Cruz, Tribal as Indigenous Social Reality and Separate Consciousness-ReIncorporating Customs and Traditions into Tribal Law, 1 TRIBAL L.J. 1, 4 (2000).

82. Robert Yazzie, 'Life Comes from It': Navajo Justice Concepts, 24 N.M. L. REv. 180 (1994). 
Another Navajo Justice has reflected that tribal courts should use autochthonous law rather than relying on state or federal law to help resolve disputes; "Navajo common law refers to the customs, traditions, and values that are applied as law and come from Navajo culture, language, and spirituality. In the absence of statutory law, the Navajo Nation courts use Navajo common law as primary and substantive law to resolve legal issues." ${ }^{\prime 3}$ These voices are at the forefront of demanding the academy critically examines what law is, what purpose it is designed to serve, and how the law's construction can meet the demands and needs of its subjects.

Professor Matthew Fletcher notes that most applications of tribal law focus on the use of customary legal principles to resolve disputes involving only tribal members. ${ }^{84}$ However, he expressly raises the issue of the application of tribal law to non-members in the context of business and contract cases; "[t]here is another category of tribal court cases that is insignificant now but will become more important in the coming years business and contract cases." ${ }^{~} 85$ Fletcher's work has gone the farthest in contemplating the role that autochthonous law might have when applied to non-Indians, albeit in the context of a non-Indian firm appearing in tribal court, perhaps as the defendant to a civil action brought by a tribal member or appealing the imposition of a fine or the authority of the tribe to promulgate regulations which circumscribe the firm's behavior. This article suggests taking the application of chthonic law to the next level and affirmatively integrating chthonic legal principles into the common law of corporate governance. By drawing from autochthonous legal principles that predate the emergence of the common law it may be possible to achieve the socially conscious ends desired by corporate governance reformers.

\section{B. Autochthonous Governance}

Having established that sovereign Indigenous communities often

83. Raymond Austin, American Indian Customary Law in the Modern Courts of American Indian Nations, 11 Wyo. L. REV. 351, 353 (2011).

84. Matthew L.M. Fletcher, The Supreme Court's Legal Culture War Against Tribal Law, 2 Intercultural Hum. RTs. L. Rev. 93, 118-119

("Tribal custom and traditional law may be difficult for nonmembers to understand, but tribal custom and tradition tends to have little or no application in cases involving nonmembers. The modern tribal court cases that rely upon tribal custom and tradition as a form of common law precedent tend to involve tribal lands and internal tribal political matters - in other words, disputes between members or the tribe.").

85. Id. at 122 . 
operate under a legal tradition distinct from the common law, it is important to document the forms of autochthonous governance so as to provide a baseline for the suggestions to reform corporate governance that follow. This section makes brief observations on the implementation of chthonic legal principles to tribal governance in four distinct areas; tribal corporations under the Indian Reorganization Act, Alaska Native Corporations, corporations founded under tribal incorporation codes, and perspectives from international Indigenous corporations.

\section{Indigenous Corporations under the Indian Reorganization Act}

While there have certainly been tribal business enterprises in some form for centuries, the United States federal government began to formally encourage their formation and development in 1934. In that year Congress adopted the Indian Reorganization Act (IRA) ${ }^{86}$ which expressly repudiated the allotment era where federal policy was focused on breaking up Indian reservations and assimilating Indian people. ${ }^{87}$ The IRA recognized and reaffirmed the inherent government-to-government nature of the tribalfederal relationship and encouraged tribes ${ }^{88}$ to organize their governments pursuant to tribal constitutions with some system of checks and balances dividing the power of tribal government. ${ }^{89}$

At the request of any Indian tribe, Section 17 of the IRA explicitly authorized the Secretary of Interior to charter a corporation which has

the power to purchase, take by gift, or bequest, or otherwise, own, hold, manage, operate, and dispose of property of every

86. Indian Reorganization Act of 1934, 48 Stat. 984, P.L. 73-383 (June 18, 1934) (codified at 25 U.S.C. $\$ 5101$ et. seq.).

87. For an excellent discussion of the Allotment Era see Judith Royster, The Legacy of Allotment, 27 ARIz. ST. L.J. 1 (1995); Jessica Shoemaker, Like Snow in the Spring Time: Allotment, Fractionation, and the Indian Land Tenure Problem, 2003 WISC. L. REV. 729 (2003); Kenneth Bobroff, Retelling Allotment: Indian Property Rights and the Myth of Common Ownership, 54 VAND. L. ReV. 1559 (2001).

88. Tribes were not required to organize themselves under the IRA, and organization under the IRA is not a prerequisite for the exercise of inherent tribal sovereignty. The Supreme Court has been very clear that sovereign rights are inherent to tribal governments and not rights delegated from the United States. See Kerr-McGee v. Navajo Tribe, 471 U.S. 195, 199 (1985) (stating, "[t]he 73d Congress, in passing the IRA to advance tribal self-government, did nothing to limit the established, pre-existing power of the Navajos. . . ).

89. Barbara Atwood, Tribal Jurisprudence and Cultural Meanings of the Family, 79 NeB. L. Rev. 577, 591 (2000) ("While a number of Indian tribes created governmental structures independent of federal policy, most followed the design of the Indian Reorganization Act. The IRA framework provided that tribal courts must obey the tribal constitution and apply laws enacted by the tribal council."). 
description, real and personal, including the power to purchase restricted Indian lands and to issue in exchange therefor interests in corporate property, and such further powers as may be incidental to the conduct of corporate business. ${ }^{90}$

The United States Supreme Court has clarified that while ostensibly chartered by the United States, Section 17 corporations are not federal instrumentalities or federal corporations, but assume the sovereign authority of the tribe itself. ${ }^{91}$

The goal of the IRA was to encourage Indian tribes to take control of their political and economic affairs; as Senator Wheeler explained from the floor

[t]his bill ... seeks to get away from the bureaucratic control of the Indian Department, and it seeks further to give the Indians the control of their own affairs and of their own property; to put it in the hands either of an Indian council or in the hands of a corporation to be organized by the Indians. ${ }^{92}$

Tribes have taken advantage of the IRA to create corporations in a range of industries in order to promote their own economic interests while conserving and protecting environmental and cultural tribal resources. ${ }^{93}$

Tribes have great latitude in structuring the governance of Section 17 entities. Some tribes have given the tribal council or other tribal governing body the responsibility for managing the tribal corporation ${ }^{94}$ while others have created an independent board of directors. ${ }^{95}$ However they are

90. 25 U.S.C. $\$ 5124$ (1934). Oklahoma tribes were initially excluded from the IRA, but these rights were subsequently extended to them in 25 U.S.C. $\$ 5203$.

91. Mescalero Apache Tribe v. Jones, 411 U.S. 145, 150 (1973) ("We also reject the broad claim that the Indian Reorganization Act of 1934 rendered the Tribe's off-reservation ski resort a federal instrumentality ...").

92. Id. at 152. (citing 78 Cong. Rec. 11125).

93. Mescalero Apache Tribe v. Jones, 411 U.S. 145 (1973) (Section 17 entity constructing and operating a ski lift); Memphis Biofuels, LLC v. Chickasaw Nation Indus., Inc., 585 F.3d 917 (6th Cir. 2009) (Section 17 entity trading in diesel fuel and soybean oil); Big Sandy Rancheria Enters. v. Becerra, 395 F. Supp. 3d 1314 (E.D. Cal. 2019) (Section 17 entity distributing, manufacturing, and importing tobacco products); Marceau v. Blackfeet Hous. Auth., 455 F.3d 974 (9th Cir. 2006) (Tribal housing authority structured as a Section 17 entity).

94. For an example of tribal council serving as the corporate board see Wippert v. Blackfeet Tribe, 859 P.2d 420, 428 (Mont. 1993) (“[T] he Tribe's corporate charter, approved pursuant to section 17 of the Indian Reorganization Act, assigns to the Tribal Council corporate powers that include the authority to borrow money from the Indian Credit Fund ...”).

95. Office of Indian Energy and Economic Development, CHOOSING A TRIBAL BUSINESS STRUCTURE, 6, https://www.bia.gov/sites/bia.gov/files/assets/as-ia/ieed/bia/pdf/idc1-032915. pdf [https://perma.cc/W8D8-2X49] ("Typically, the corporation is managed by a board of 
structured "the IRA has had a significant impact on the development of the tribal government owned corporation." ${ }^{, 96}$ Professor Angelique EagleWoman (Wambdi WasteWin) has done some fascinating and important work on the construction, purpose, and governance of tribal corporations. She observes that "[t]ribal corporations serve functions greater than other for-profit corporations as they embody the livelihood of communities as well as the self-enrichment of corporate officers and employees." clearing the way for tribes to be creative with corporations and to mix traditional culture and understanding with the corporate form, "tribal commercial ventures are steadily reemerging in the life of the tribal community." 98

Almost 100 years after the enactment of the IRA it is difficult to imagine economic activity in Indian country without Section 17 chartered corporate entities. These tribal businesses occupy nearly every facet of economic life - from operating tribal housing authorities to agriculture, manufacturing, tourism, and marketing. ${ }^{99}$ While every entity may be run or structured differently, they share a common characteristic of seeking both profit generating activity to support the tribal coffers while managing their respective businesses, land, and resources in a manner that is respectful of tribal custom and tradition. Insights taken from these Section 17 entities are a critically important component of the suggestions this article makes for the application of Indigenous thought to modern non-Indigenous corporations.

\section{Alaska Native Corporations}

The Alaska Native Claims Settlement Act (ANCSA) ${ }^{100}$ represents the greatest experiment with Indigenous corporations since the IRA. Enacted during the Nixon administration, ANCSA was designed to settle a plethora of land and resource claims made by Native Alaskan individuals and village governments which created legal uncertainty surrounding land ownership

directors, the members of which are appointed by the tribal government.").

96. Angelique A. EagleWoman and (Wambdi A. WasteWin), Tribal Nation Economics: Rebuilding Commercial property in Spite of U.S. Trade Restraints - Recommendations for Economic Revitalization in Indian Country, 44 Tulsa L. Rev. 383, 394 (2008) (Wambdi A. WasteWin "is the author's Dakota name" and since the author made a point of using both names when she authored the piece, I want to make a special point of using both names when I cite the scholarship).

97. Id. at 397.

98. $I d$.

99. Supra note 93.

100. Alaska Native Claims Settlement Act of 1971, 85 Stat. 688, P.L. $92-203$ (Dec. 18, 1971) (codified at 43 U.S.C. $§ 1601$ et. seq.). 
and relatedly raised costly potential legal barriers to the development of Alaska's natural resources. ${ }^{101}$ ANCSA intended to treat the relationship between the federal government and Native Alaskan tribes differently than the federal-tribal relationship in the contiguous United States by announcing that there would be no "reservation system or ${ }^{102}$ lengthy wardship or trusteeship". ${ }^{103}$ Instead ANCSA established more than 200 village $^{104}$ and thirteen regional corporations ${ }^{105}$ which would together be responsible for managing Native Alaskan lands profitably and for the benefit of their communities. ${ }^{106}$ Collectively known as Alaska Native Corporations (or ANCs), they have been at the vanguard of experimentation with the application of chthonic law and corporate governance.

Alaska Native Corporations are fascinating entities because they were created both to return a profit for their Native shareholders but also to manage land and resources in ways that are consistent with the cultural values of the communities they serve. As Professor EagleWoman articulates, "ANCs were meant to participate in the U.S. market economy as other corporations with the added responsibility of providing benefits for the Native community composed of the Native shareholders - a type of hybrid corporate purpose." ${ }^{\prime 107}$ ANCs meet this dual commitment in a variety of

101. For an exceptional discussion of ANCSA, its purpose, its policies, and its implementation see DAVID S. CASE AND DAvid A. Voluck, Alaska NATIVES AND AMERICAN LAws (University of Alaska Press, 3rd ed. 2012). See also Heather Kendall-Miller, ANCSA and Sovereignty Litigation, 24 J. LAND ResourCeS \& ENVTL. L. 465 (2004); Stephen Colt, Alaska Natives and the "New Harpoon": Economic Performance of the ANCSA Regional Corporations, 25 J. LAND Resources \& EnvtL. L. 155 (2005); Robert T. Anderson, Sovereignty and Subsistence: Native Self-Government and Rights to Hunt, Fish, and Gather after ANCSA, 33 ALASKa L. REV. 187 (2016).

102. 43 USC $\S 1601(b)$. Virtually all Native Alaskan communities accepted ANCSA and organized under it, but the Metlakatla Indian Community refused. Accordingly, it retains its Annette Island Reserve as a reservation and has organized itself under the IRA. See Parker Drilling Co. v. Metlakatla Indian Community, 451 F. Supp. 1127, 1131 (D. Alaska 1978). The United States may take new lands into trust for Native Alaskan communities expanding the scope of Indian country in Alaska. See Akiachak Native Cmty. v. U.S. Dept. of Interior, 827 F.3d 100 (D.C. Cir. 2016).

103. 25 USC $\S 1601(b)$.

104. Village Corporations are authorized under 43 USC §1607(a) (2012).

105. Regional Corporations are authorized under 43 USC $\$ 1606(a)$, (c) (2012). The twelve geographically centered corporations are listed in subsection (a) and the thirteenth corporation - incorporated for the benefit of Native Alaskans living outside of Alaska - is provided for in subsection (c).

106. See generally Douglas M. Branson, Still Square Pegs in Round Holes? A Look at ANCSA Corporations, Corporate Governance, and Indeterminate Form or Operation of Legal Entities, 24 AlASKA L. REV. 203 (2007) (examining the laws governing Alaska native corporations).

107. See EagleWoman supra note 96, at 414 (discussing cultural value of providing 
interesting ways which provide opportunities to examine Indigenous corporate governance.

Professor Douglas Branson has documented just some of the ways that the governance of ANCs has deviated from the shareholder primacy model. Consistent with autochthonous principles, elders play a particularly important role $^{108}$ as both beneficiaries of corporate services and as shareholders of the corporations themselves; "Alaska Natives have always accorded special status to their elders. Several regional and village corporations have sought to add flesh to the commitment. They have set aside substantial resources to provide elder benefits, above distributions to all shareholders." 109 These protections are undertaken with the tacit approval of all shareholders and are built into the structure of the ANCs; "ANCSA provides, if not for the payments themselves, then at a minimum a means for making them. The Act authorizes Native corporations to amend their articles of incorporation to provide for 'Natives who have obtained the age of sixtyfive." "110 ANCs accomplish this by creating a new class of shares (elder preference shares) and so payments are made consistent with corporate law, not a corporate subsidy of any group of persons - but a special distribution to all holders of a unique class of stock. ${ }^{111}$

Consistent with autochthonous principles, ANCs have taken some lands they control that are particularly culturally or environmentally important to Native groups and placed them in settlement trusts "arguably intended to put certain Native historical sites and similar lands, not expanses of land or shareholder funds, out of creditors' or shareholders' reach."112 This separation of culturally valuable lands and resources from the corpus of corporate assets is certainly consistent with chthonic principles requiring the preservation of sacred sites or the careful stewardship of land largely viewed as critically important to the community, but it is hard to reconcile with

additional benefits to elders).

108. Maude Blair, Issuing New Stock in ANCSA Corporations, 33 ALASKA L. REv. 273, 274 (2016).

109. Douglas M. Branson, supra note 106, at 219.

110. Id. (citing 43 U.S.C. $\$ 1606(\mathrm{~g})(2)(\mathrm{B})(\mathrm{iii})(\mathrm{I})(2000)$ ).

111. See id.

("The corporation may make additional payment to elders once a corporation has formally proposed a resolution, allowed whatever debate to ensue, obtained a shareholder vote, and filed articles of amendment with the Alaska Secretary of State authorizing an additional class of shares, and distributed newly authorized shares to elders. Although they are still distributions under corporate law, payments are made with respect to shares (elder-preference shares), not with respect to shareholders.").

112. Id. at 220 . 
shareholder primacy which is focused on maximizing wealth or a return on investment.

Alaska Native Corporations also have limitations on transferability and ownership of their shares. Shares may be issued upon birth and retired upon death, ${ }^{113}$ making the number of shares outstanding at any time highly variable. ${ }^{114}$ Maude Blair, former Vice-President of the Alaska Federation of Natives, has documented some of the peculiarities of ANC's shares. She notes that since most shareholders own equal numbers of voting shares obtaining a quorum requires not just a majority of shares but a majority of shareholders. ${ }^{115}$ Any selection of directors or other corporate decisions thus require a political consensus that can command the support of a majority of shareholders, and this requires the ANC to think about its constituencies differently than many traditional corporations. ${ }^{116}$ Decisions undertaken at ANC shareholder meetings are structurally required to meet a double majority - resolutions passed only if they command the support of both a majority of voting shares but also a majority of shareholders. These protections find their roots culturally expressed in autochthonous values that prioritize consensus and egalitarian participation in governance.

\section{Tribal Incorporation Codes}

The law on Indigenous corporations extends beyond those firms created by the tribal sovereign itself under the permission or auspices of federal law like the IRA and ANCSA. One of the concomitant powers of sovereignty is the ability to charter corporations. ${ }^{117}$ Several Indian tribes have created their

113. See Blair, supra note 108 , at 280 ("The stock can be a life estate, where the stock reverts back to the issuing corporation upon the death of the shareholder to whom it was issued. Alternatively, the stock can be inheritable, as is the original Settlement Common Stock.").

114. Grant Christensen, What Does It Mean to Be Sustainable? Regulating the Relationship between Corporations and Indigenous Peoples, in THE CAMBRIDGE HANDBOOK of Corporate Law, Corporate Governance, And Sustainability 416 (Beate Sjåfjell \& Christopher M. Bruner eds., Cambridge Univ. Press 2020).

115. See Blair, supra note 108 , at 280

("A majority of the shares entitled to vote, represented in person or by proxy, constitutes a quorum at a meeting of shareholders, though a corporation can amend its articles of incorporation to lower the quorum requirements to as little as one-third of the voting shares. Corporations with large shareholder bases can have trouble obtaining a quorum, and many ANCSA corporations offer door prizes for shareholders who attend in person or turn in a proxy in an effort to increase participation in the meeting.").

116. See $i d$. at 279 (discussing the special treatment elders receive).

117. See Geoffrey D. Strommer \& Stephen D. Osborne, 'Indian Country' and the Nature 
own business or incorporation codes which permit entities to be organized/chartered under the tribal sovereign instead of organized/chartered under state law. ${ }^{118}$ If a tribe lacks a formal incorporation code, a tribe may charter a corporation through the direct action of the tribal council or other related branch of tribal government. ${ }^{119}$ While these entities may share the general features of a partnership, LLC, or corporation - there is nothing inherent about these forms that must be duplicated at the tribal level. Instead, tribes are free to experiment with the development of other corporate forms and redefine the nature of the shareholder and of the firm under the contours of chthonic law. ${ }^{120}$

Corporations chartered under tribal law need not be created or owned by the tribe or its members, and admittedly are not always created for munificent ends. ${ }^{121}$ Depending on how the tribal code is written anyone may take advantage of the benefits and restrictions imposed by tribal law by creating a tribally chartered entity. ${ }^{122}$ In keeping with the thesis of this article that tribal law and Indigenous thinking enable corporate governance reform, even when tribal business codes look similar to their state counterparts there are notable differences to promote equitability.

The Winnebago Business Code provides one example. It requires a

and Scope of Tribal Self-Government in Alaska, 22 ALASKA L. REV. 1, 12 (2005) ("Included in the inherent sovereign powers of a tribe, sometimes implemented in its constitution, is the power to charter a corporation under tribal law.").

118. See The Winnebago and Citizen Potawatomi Nation are notable examples. See Evan Way, Raising Capital in Indian Country, 41 AM. Indian L. REV. 167, 197-98 (2016) ("The Winnebago Tribe accomplished this goal by creating a comprehensive tribal business code, which allowed the formation of wholly owned tribal businesses."). The article continues to talk about the development of a Community Development Financial Institution (CDFI) by the Citizen Potawatomi Nation). See also E. BAnd of Cherokee Code, ch. 55; Tribal Codes of the Hoopa Valley Tribe, tits. 51-57; Navajo Nation Code, tit. 5 ch. 19.

119. See I.R.S. Priv. Ltr. Rul. 199909013 (Nov. 25, 1998) (stating tribal council can form a tribal corporate entity to manage its timber resources).

120. While there is a great deal of latitude in the forms of entities tribes may create a tribal government itself may not be a shareholder in an S-corporation because it is not an individual subject to federal income tax. See Rev. Rul. 2004-50, 2004-22 I.R.B. 977. However as long as the tribe is not a shareholder in the concern, an entity created under tribal law may qualify for treatment as an S-corporation on the same basis as corporations operating under state law because an entity created under tribal law is still a "domestic corporation."

121. For a discussion of the potential to abuse the tribal incorporation rules for nefarious ends like usurious lending see Creola Johnson, America's First Consumer Financial Watchdog is on a Leash: Can the CFPB Use Its Authority to Declare Payday-Loan Practices Unfair, Abusive, and Deceptive?, 61 CATH. U.L. REV. 381, 399-401 (2012).

122. See id. (discussing non-Indians forming businesses under tribal law in an attempt to take advantage of tribal sovereign immunity). See generally Jenadee Nanini, Tribal Sovereignty and Fintech Regulations: The Future of Co-Regulating in Indian Country, 1 GEO. L. TECH. REV. 503 (2017) (describing how third parties can exploit tribal immunity). 
presumption that "[a] corporation must allow cumulative voting for directors." 123 The SEC explains that "cumulative voting is a type of voting system that helps strengthen the ability of minority shareholders to elect a director." ${ }^{24}$ When there are multiple open seats on a Board, shareholders in a cumulative voting system may cast all of their votes for a single nominee instead of the more limited rule providing for one vote per share per seat. ${ }^{125}$ Jeffrey Gordon, co-director of the Center for Global Markets and Corporate Ownership at Columbia, observes that cumulative voting "was a common feature in corporate governance until the managerialist assaults of the $1950 \mathrm{~s}$ "126 and that by the 1990s "[n]o important corporate law jurisdiction maintained mandatory cumulative voting." 127 Among its more salient features, cumulative voting acts as "a vehicle for proportional board representation of significant shareholder minorities" $" 128$ thereby ensuring a greater diversity of voices on the board and greater control by minority shareholders.

Some tribes have radically reconceptualized the law surrounding entities, implementing novel legal positions that dramatically redefine corporations, trusts, and/or shareholders. In 2019 the Yurok Tribe adopted a resolution recognizing the legal rights of the Klamath River. ${ }^{129}$ The River has functionally become a legal person. Individuals who violate the rights of the Klamath River may be sued by the River for damages in Yurok Tribal Court. ${ }^{130}$ So who represents the River's legal interests? The Tribe is presently deciding how the interests of the River will be protected, but under autochthonous principles the River will be functionally run like an Indigenous conceptualization of a firm. It has a concrete set of resources which must be managed, protected, preserved, and developed by a group of persons to promote the River's health and sustainability (think of them as the managers) who are ultimately subject to the Yurok tribal government (the

123. Winnebago Business Corporation Code, arts. 11-111(2)(2) (2015), http://www.winnebagotribe.com/images/joomlart/corporate/tribe/court/tribalcode/2015-WT N-TITLE-11-Business-Corporations.pdf [https://perma.cc/8X94-2M5F].

124. Securities and Exchange Commission, Cumulative Voting, https://www.sec.gov/fastanswers/answers-cumulativevotehtm.html [https://perma.cc/PZ4G-BA9S].

125. Id.

126. Jeffrey Gordon, Institutions as Relational Investors: A New Look at Cumulative Voting, 94 COLUM. L. REV. 124, 127 (1994).

127. Id. at 146 .

128. Id.

129. Geneva E. B. Thompson, Codifying the Rights of Nature: The Growing Indigenous Movement, 59 Judges' J. 12 (2020).

130. See id. ("[T] he Yurok Tribe will clarify its authority to represent the Klamath River and prosecute against any person or entity that violates the Klamath River's rights in Yurok Tribal Court."). 
Board). Yurok citizens who believe the River's interests are not being appropriately expressed act as shareholders who may change the tribal government (the Board) by voting at tribally held elections. A different tribal government may in turn name new tribal members (managers) to act in the River's best interest.

\section{International Indigenous Corporations}

The twenty-first century has seen a remarkable consensus emerge regarding the need to respect the rights of Indigenous people at an international level. In 2007 the United Nations General Assembly approved the U.N. Declaration on the Rights of Indigenous Peoples (UNDRIP). ${ }^{131}$ While several countries initially voted against the Declaration, their leaders have all subsequently reversed course ${ }^{132}$ - making a strong argument that the declaration represents customary international law. ${ }^{133}$ UNDRIP does not explicitly mention Indigenous corporations but it tacitly encourages their development. Among the goals in UNDRIP's preamble, member states are "Welcoming the fact that indigenous peoples are organizing themselves for ... economic . . . enhancement ..." ${ }^{\prime 34}$ and Article 5 guarantees the right of Indigenous people to maintain their own economic institutions while not foregoing their ability to engage with the economic institutions of their concomitant member states. ${ }^{135}$

It is therefore unsurprising that Indigenous corporations are not unique to the United States. Perhaps the most developed model comes from New Zealand. Almost sixty years after the United States enacted the IRA, New Zealand's parliament enacted the Te Ture Whenua Māori Act of 1993 (Māori

131. G.A. Res. 61/295, (Oct. 2, 2007), https://www.refworld.org/docid/471355a82.html [https://perma.cc/N3X7-GPF5].

132. See Kent Williams, How the Charter Can Protect Indigenous Spirituality; Or, the Supreme Court's Missed Opportunity in Ktunaxa Nation, 77 U. Toronto FAC. L. Rev. 1, 11 (2019) (noting that all of the original dissenters to UNDRIP have since accepted it).

133. Id. See also Allison M. Dussias, Friend, Foe, Frenemy: The United States and American Indian Religious Freedom, 90 Denv. U.L. Rev. 347, 428 (2012)

(“Some of UNDRIP's specific provisions also reflect existing norms of customary international law. Moreover, UNDRIP as a whole is best understood as a document that elaborates, 'in the specific cultural, historical, social and economic circumstances of indigenous peoples,' on already recognized 'fundamental human rights that are deemed of universal application."').

134. G.A. Res. 61/295, supra note 131.

135. See $i d$. at art. 5. ("Indigenous peoples have the right to maintain and strengthen their distinct political, legal, economic, social and cultural institutions, while retaining their right to participate fully, if they so choose, in the political, economic, social and cultural life of the State.”). 
Land Act) permitting the creation of Māori Incorporations. ${ }^{136}$ Gwendolyn Gordon, a professor at the Wharton School at the University of Pennsylvania who has done extensive fieldwork with the Māori, explains that a Māori Incorporation is more than just a Māori-owned corporation; "In contrast to duties of directors of other companies, the duties of directors of Māori incorporations (and the courts' standards for the determination of the breach of those duties) are remarkably vague. The Act's primary priority is to limit the alienation of Māori land." ${ }^{137}$ Because of their connection to land, Māori Incorporations make decisions differently than a traditional corporation. When the preservation of the land base and the protection of the land are both important to shareholders and required under the corporate charter, directors are not merely encouraged, but forced, to take into account sustainability when making decisions. As Professor Gordon articulates "Māori incorporations thus constantly negotiate — and I argue, are constituted by - this balancing act between profit and social responsibility. The varied ways in which New Zealanders understand this concatenation of freedoms and protections give rise to an ideation of the relationship between the corporation and the land not as one of mere management for profit, but as guardianship of the land." 138

One more example from Professor Gordon's work will help contextualize the matter. She describes her work with the Wakatū Incorporation, working with several Māori shareholders to establish a longterm business plan:

The people involved with Wakatū, from management to shareholders to employees, utilize the history of the ancestors of the tribes from which the shareholders hail in order to assert links of kinship between the whanau (the shareholders and their extended families) and the corporation.... Wakatū is a corporation grown from the ground that holds the bones buried here of generations past, and from which generations to come will grow. These bones were the skeleton on which the body of the organization was built, a body that was supported by the weaving of literal genealogical links between the corporation, the shareholders and their extended families, their ancestors, and the land. The long-term business plan looked to genealogical ties to

136. Te Ture Whenua Māori Act/Māori Land Act 1993 (N.Z.) (Available at: http://www. legislation.govt.nz/act/public/1993/0004/latest/whole.html\#DLM289897) [https://perma.cc/ D8GK-JDCB].

137. Gwendolyn Gordon, Culture in Corporate Law or: A Black Corporation, a Christian Corporation, and a Maori Corporation Walk into a Bar . . , 39 Seattle U. L. Rev. 353, 388 (2016).

138. Id. at 389 . 
suggest plans for a corporate body that extended out to the shareholders of generations past and generations to come. This, by the way, was a business plan for the next five hundred years. ${ }^{139}$

Embedded within, and central to, Professor Gordon's observation are the hallmarks of autochthonous legal tradition. The business plan explicitly takes into account the obligation of the Incorporation to be responsive to the needs of the community and defines those needs as unbounded by time; decisions are consciously taken only after consideration of the needs of the ancestors of the past and of the impact a decision will have on future generations. While this deliberative process might be less profitable in the short run, ${ }^{140}$ it preserves resources and land which are vital components of a strong and social community. ${ }^{141}$ When corporate governance is focused on making decisions that ensure the corporation is still a profitable and going concern five centuries in the future it makes fundamentally different decisions about the conservation of its resources. There is a lot here for modern corporate law to learn from autochthonous legal principles.

\section{INDIGENOUS CORPORATE GOVERNANCE}

Having established the strong tradition of both autochthonous law and Indigenous corporate governance this paper now makes three direct suggestions for how corporate law could learn from chthonic legal principles in order to improve corporate governance. Discussed in turn, these suggestions each draw from Indigenous legal traditions grounded in values expressed in the chthonic law and drawing from the four iterations of Indigenous corporations discussed in Part III.

It is noteworthy that this Indigenous legal approach does not require the wholescale abandonment of rules based in the common law legal tradition.

139. Id. at 386 .

140. See id. at 388

("As is the case with all of these TTWMLA organizations, the protections put into place by the Act to secure the interests of the beneficial owners of Māori land against alienation make it more difficult for boards to secure approval for the sale of land and (not altogether coincidentally) more difficult to conduct business at a profit.").

See also Benedict Kingsbury, First Amendment Liberalism as Global Legal Architecture: Ascriptive Groups and the Problems of the Liberal NGO Model of International Civil Society, 3 CHI. J. INT'L L. 183, 191-92 (2002) (discussing the link between shareholders, managers, and the profitability of Māori Incorporations).

141. Gordon, supra note 137, at 387 ("The people who are of the tribes and subtribes affiliated with that land, or whose families have owned that land or had traditional authority over it for generations, might have particular feelings about its management."). 
Indeed, such a suggestion would be an interesting academic exercise but would be a non-starter in terms of actual reform. In reality, common law rules are rooted in autochthonous tradition. ${ }^{142}$ Rather than imagine these suggestions for corporate governance reform as a further deviation from, a reform to, or a refinement of, the common law-I hope that the reader thinks of them as a return to the principles of governance that have been lost over time. A return to the chthonic tradition and then a reconstruction of corporate law within the common law tradition.

A couple examples serve to illustrate the point that an autochthonous tradition is not antithetical to the common law. In 2013, as part of Congress' reauthorization of the Violence Against Women Act, ${ }^{143}$ tribal courts were able to assert their inherent powers ${ }^{144}$ of criminal jurisdiction over nonIndians to prosecute acts of domestic violence and dating violence. ${ }^{145}$ In order to assert these powers Congress instructed tribal courts that they must provide non-Indian criminal defendants with legal counsel. ${ }^{146}$ A Pascua Yaqui tribal leader explains that such procedural rights are perfectly "consistent with Yaqui tradition and culture, namely protecting our people and providing fairness to the accused." 147 The Yaqui leader justified this conclusion by relating it back to autochthonous principles;

Historically, law enforcement functioned largely through

142. GLENN, supra note 58 (discussing how all other legal traditions including the common and civil law emerged from the original legal tradition - chthonic law).

143. Violence Against Women Reauthorization Act of 2013, Pub. L. No. 113-4, 127 Stat. 120 (Mar. 7, 2013) (The relevant parts of the reauthorization for the power of Indian tribes is now codified at 25 U.S.C. $\S 1304$ ). For general discussion about the expanded powers of VAWA see Adam Crepelle, Tribal Courts, the Violence Against Women Act, and Supplemental Jurisdiction: Expanding Tribal Court Jurisdiction to Improve Public Safety in Indian Country, 81 MonT. L. Rev. 59 (2020); Jessica Allison, Comment, Beyond VAWA: Protecting Native Women from Sexual Violence Within Existing Tribal Jurisdictional Structures, 90 U. Colo. L. REV. 225 (2019).

144. See 25 U.S.C. $\S 1304(b)(1)$ (2018) ("[T]he powers of self-government of a participating tribe include the inherent power of that tribe, which is hereby recognized and affirmed, to exercise special domestic violence criminal jurisdiction over all persons.").

145. See 25 U.S.C. 1304(c) (2018) (listing the crimes for which Indian tribes may prosecute non-Indians as domestic violence, dating violence, and violation of a protection order).

146. See 25 U.S.C. 1304(f)(2) (2018) ("[T] p provide indigent criminal defendants with the effective assistance of licensed defense counsel, at no cost to the defendant, in criminal proceedings in which a participating tribe prosecutes a crime of domestic violence or dating violence or a criminal violation of a protection order"). For critical discussion of this power see Jordan Gross, VAWA 2013's Right to Appointed Counsel in Tribal Court ProceedingsA Rising Tide that Lifts All Boats or a Procedural Windfall for Non-Indian Defendants?, 67 CASE W. Res. L. ReV. 379 (2016).

147. Angela R. Riley, Crime and Governance in Indian Country, 63 UCLA L. Rev. 1564, 1600 (2016). 
ceremonial societies and clan affiliations. Having someone speak on your behalf and ensuring fairness are both 'deeply rooted in Yaqui indigenous tradition and practice,' and are based in tribal cultures that 'pre-date the U.S. Constitution and the Bill of Rights and are rooted in beliefs that are arguably as old as English Common Law. ${ }^{148}$

That chthonic legal traditions are not incompatible with much of the common law discourse used in modern judgments is echoed throughout the tribal courts. Nell Jessup Newton, former Dean of Notre Dame Law School and Editor of Cohen's Handbook of Federal Indian Law, has done some groundbreaking work on debunking stereotypes associated with tribal courts. ${ }^{149}$ After studying a year of tribal court opinions published by twenty different tribal courts Dean Newton observes how similar tribal law often is to its common law counterpart - even when the origins of the rights expressed were different the procedural outcomes tended to coalesce. ${ }^{150}$ For example, in Hall v. Tribal Business Council ${ }^{151}$ the Tribal Court of the Three Affiliated Tribes (Mandan, Hidatsa, Arikara) reasoned that while tribal courts are not governed by the Constitution's due process requirement; tribal law required applicants for grazing unit leases " "be treated culturally and legally with dignity and appropriate fairness,' traditions that 'are central to the history of the Three Affiliated Tribes"' and therefore tribal law required applicants be afforded a tribal right akin to due process. ${ }^{152}$

Against this background this section makes a pointed argument for three changes in corporate governance that find their origins in autochthonous legal principles and do not directly conflict with the common law. First, that corporate law should be altered to eliminate the pressures of short-termism that managers and boards face from their investors/shareholders. Second, that in order to eliminate this short-term thinking, and to recognize the sometimes-conflicting interests of stakeholders and shareholders, that changes be implemented to the construction of shares and their voting rights. Finally, recognizing that institutional investors or a couple large owners can skew the direction of a corporation disproportionately, that there be some inherent limitations on ownership. Changes to ownership include vesting stakeholders with shares

148. $I d$.

149. Nell Jessup Newton, Tribal Court Praxis: One Year in the Life of Twenty Indian Tribal Courts, 22 Am. InDiAn L. ReV. 285 (1998).

150. See Id. at 295 ("[R] eady access to tribal court opinions could dispel some of the stereotypes regarding the ability of tribal courts to administer justice fairly.").

151. Hall v. Tribal Bus. Council, 23 Indian L. ReP. 6039 (Fort Berthold Dist. Ct. 1996).

152. Newton, supra note 149, at 344. 
and imbuing shares with some limited life span (akin to a life estate) which will structurally make it more difficult for any shareholder to command a majority of shares.

\section{A. Time Horizons and the Elimination of Short-Termism}

Among the greatest ills in modern corporate governance is that shareholder primacy creates incentives for managers to seek short term profits at the expense of longer-term investment or addressing the concerns of stakeholders who do not own an appreciable number of shares (including employees, communities, and the environment). ${ }^{153}$ This short-termism emerges because corporate managers are hired and fired by a Board, which is itself elected by shareholders. ${ }^{154}$ A dip in corporate profitability or a reduction of a dividend to shareholders in order to invest in green technology or pay higher wages is often used as the progenitor of change. ${ }^{155}$ The Board of Directors is incentivized to fire a CEO who fails to maximize quarterly returns. ${ }^{156}$ A Board that permits a CEO to sacrifice profitability to address the concerns of employees or the environment is itself subject to removal by a vote of shareholders at the next annual meeting. ${ }^{157}$ Even if the Board survives legal action by shareholders - going all the way back to Dodge v. Ford Motor Company - a single frustrated shareholder may use the courts to limit the discretion of management and to demand a share of corporate profits that might otherwise be used to promote alternative social, humanitarian, or environmental goals. ${ }^{158}$

This short-term thinking is anathema to autochthonous principles which prioritize sustainability, resource conservation, and egalitarianism.

153. See David G. Yosifon, The Public Choice Problem in Corporate Law: Corporate Social Responsibility After Citizens United, 89 N.C. L. REV. 1197, 1237 (2011) ("Under shareholder primacy, directors have the incentive and the opportunity to appropriate value from workers and consumers on behalf of shareholders.").

154. Id.

155. See Charles M. Elson, The Duty of Care, Compensation, and Stock Ownership, 63 U. CIN. L. REV. 649, 662-63 (1995) ("If management performs sub-standardly, the board as an effective monitor must either provide executives with new direction or replace them.").

156. $I d$.

157. See Margaret M. Blair, Directors' Duties in a Post-Enron World: Why Language Matters, 38 WAKE Forest L. Rev. 885, 887-88 (2003) (citing and summarizing this scholarship before critiquing it).

158. Dodge v. Ford Motor Co., 170 N.W. 668 (Mich. 1919). But see Eric W. Orts, Beyond Shareholders: Interpreting Corporate Constituency Statutes, 61 GeO. WASH. L. REV. 14, 91 (1992) (discussing the American Law Institute and its proposals on duty of care which permit the expenditure of profits for humanitarian purposes when "ethical considerations that are reasonably regarded as appropriate to the responsible conduct of business"). 
Indigenous theories of corporate governance take a very different perspective on the time horizons of corporate decision-making. ${ }^{159}$ Indigenous governance is unbounded by a linear notion of time, demanding that decisions are taken not with a perspective on quarterly returns but by accounting for the interests of elders and ancestors as well as future yet unborn generations. ${ }^{160}$ When creating a business plan the founders of one Māori Incorporation talked about the business being built literally on the bones of its ancestors, and crafted a plan designed to provide for generations five-hundred years in the future. ${ }^{161}$ The "Iroquois, spiritual ancestors of sustainable development, felt compelled to plan [ahead] seven generations." "162 Seneca Faithkeeper Oren Lyons explains:

The Peacemaker taught us about the Seven Generations. He said, when you sit in council for the welfare of the people, you must not think of yourself or of your family, not even of your generation. He said, make your decisions on behalf of the seven generations coming, so that they may enjoy what you have today. ${ }^{163}$

As Professor Michalyn Steele explains:

[T] he Seven Generations principle bound the delegates to take the long view in their planning and deliberations. Leaders had a political and moral duty to the whole: not just to their contemporaries, but to the women who came before them and the children who would follow. This restraint on the temptation to

159. See Valerie J. Phillips, Parallel Worlds: A Sideways Approach to Promoting Indigenous-Nonindiegnous Trade and Sustainable Development, 14 Мich. ST. J. INT'L L. 521, 532 (2006)

("Ironically, the indigenous conception of time and change is more in-sync with the developments in modern science than that of Euro-America. Indeed, the western conception of markets is that they are "natural" and "private" pseudoscientific entities upon which everyone must blindly rely for sustenance. In contrast, indigenous markets explicitly serve the local, collective needs of all within the society. It cannot be said often enough that Law and Economics reflects culture; it is tribal values and the welfare of the people that determine economic pursuits and policy.").

160. See Angelique EagleWoman (Wambdi A. Wastewin), Cultural and Economic SelfDetermination for Tribal Peoples in the United States Supported by the UN Declaration on the Rights of Indigenous Peoples, 28 PACE ENVTL. L. REv. 357, 360-61 (2010) (describing the importance embedded in many Indigenous traditions of thinking about the effect of a decision seven generations in the future).

161. See Gordon, supra note 137, at 386 (sharing how some indigenous people perceive the corporate form).

162. Emily Fisher, Sustainable Development and Environmental Justice: Same Planet, Different Worlds?, 26 Environs ENVTL. L. \& POL'y J. 201, 205 (2003).

163. Michalyn Steele, Indigenous Resilience, 62 ARIZ. L. REV. 305, 325 (2020). 
act on short-term, or self-interest has been an important aspect of resilient tribal systems. ${ }^{164}$

An autochthonous approach to governance requires that corporate decisions take into account the potential approbations of former shareholders and the interests of future-yet unknown-shareholders. Changing the constituencies to which a Board is responsive will necessarily change the decisions that are made.

Short-term thinking serves few interests. Ironically, often it does not even serve the interests of shareholders in whose name it has arguably been adopted. Investing for the long term promises to yield more consistent and sustained/sustainable returns. ${ }^{165}$ While this does sacrifice some short-term profits and will disappoint persons who hold shares only for short term gains, thinking along greater timescales ultimately will promote benefits to the investor class and the environment. As Professor Benjamin Richardson has noted "investors are cajoled to take a long-term outlook to achieve optimal returns while environmental policymakers are expected to foster intergenerational stewardship of nature." ${ }^{\prime 66}$ At this point the correlation between longer investment time horizons and the ability to enact socially conscious and sustainable policy goals becomes obvious.

So how does corporate governance learn from autochthonous principles in order to encourage corporate decision-making to reject the pressures of short termism? The answer lies in changing the power and incentives of decision makers. As Professor Steele observes from Haudenosaunee (Iroquois) tradition; "If a delegate was determined to be making decisions motivated by self-interest, rather than for the good of the community, born and unborn, the clan mother could strip the delegate of responsibilities and replace that delegate with another."167 Autochthonous law suggests that by removing leaders who engage in short-termism or who focus on the profits

164. Id.

165. See Heather M. Field, Throwing the Red Flag: Challenging the NFL's Lessons for American Business, 38 J. CORP. L. 381, 386 (2013)

("Of course, many shareholders invest for the short-term, but unlike a sports bet or many derivative contracts, an investment in stock is generally not time-limited by its own terms. Thus, the greater prevalence of long-term investing in stocks suggests that shareholders are less likely to benefit from the manufacture of volatility and may have more tolerance for business plans that produce long-term benefits.").

166. Benjamin Richardson, Aligning Social Investing with Nature's Timescales, in THE CAmbridge Handbook of Corporate Law, Corporate Governance, and Sustainability 566 (Beate Sjåfjell \& Christopher M. Bruner eds., Cambridge University Press) (2020).

167. Steele, supra note 163 , at 325 . 
for shareholders at the expense of employees, the community, or the environment, that corporate governance would naturally adopt a more stakeholder focused and sustainable direction.

If CEOs were less afraid they would be fired or replaced if they permitted profits to decline in order to promote more notable social and environmental causes supported by the communities in which they were situated, then corporate management would become notably more stakeholder centered. If Boards did not fear being replaced by shareholders when they permit management to undertake business decisions that are more responsive to employees, community members, and the environment, then Boards would more freely hire, promote, and retain stakeholder centered leaders. In order to change the current incentives and challenge the shareholder primacy model chthonic law suggests policy changes to both the voting rights of shareholders and the reconceptualization of ownership itself.

\section{B. Voting Rights}

Autochthonous law has much to suggest to reform the nature of voting rights possessed by shareholders in order to encourage corporate behavior to be more responsive to stakeholders and break out of the trap of shorttermism. Two suggestions are offered here; (1) shares should not be immediately vested with voting rights but rather should acquire voting rights only over time, and (2) placing limits on the number/proportion of shares any one individual or entity may vote - perhaps by issuing shares with variable voting rights.

\section{Maturity of Voting Rights}

One concrete proposal to structurally make short-termism more difficult would be to issue shares with voting rights that only mature after they have been held for a certain amount of time. Alaska Native Corporations have pioneered experiments with corporate voting rights. Many ANCs have provisions for parents to petition for the issuance of shares upon the birth and enrollment of their minor children. ${ }^{168}$ Some ANCs issue 100 shares to each new member and others have alternative share issuance schemes where, for example, a minor may be issued thirty shares initially and then issued additional seventy shares after graduating from high school and reaching the age of eighteen, or reaching the age of twenty-one without

168. Maude Blair, Issuing New Stock in ANCSA Corporations, 33 AlASKA L. REV. 273, 282 (2016). 
a high school diploma. ${ }^{169}$ These shares do not all necessarily convey voting rights. For example, one ANC (Calista Corporation) had its shareholders vote to create new stock for the descendants of original shareholders, but it further limited the voting rights to members who had turned eighteen. ${ }^{170}$ Whether voting rights are delayed, or whether additional shares/rights are issued after being held for a designated amount of time, this autochthonous experiment in reimagining voting rights holds valuable lessons for modern corporate governance.

Because annual meetings require a quorum, and in many rural Alaskan societies virtually everyone in the community might be a shareholder, ANCs often host entire families at shareholder meetings. ${ }^{171}$ When shares are issued at birth (or shortly thereafter), a child has potentially eighteen years of attending shareholder meetings with their family and their community before they become voting shareholders themselves. Participation as an active shareholder becomes engrained. When shares obtain voting rights only upon reaching the age of eighteen, or when additional shares are distributed at milestones such as graduating from high school or reaching majority, there is a learned process of shareholder behavior. Shareholders will have watched corporate performance over almost two decades of meetings before casting their first votes. By attending the meetings, reviewing prospectuses, and discussing issues of corporate strategic direction and investment, these minor shareholders ${ }^{172}$ have become privy to shareholder decision-making about the direction of the ANC and have seen the support generated among their peers, family, friends, and elders for decisions taken to forgo short term returns in the past that have yielded greater dividends over time. ANC shareholders who vote only after watching corporate governance and decision making for more than a decade are much more likely to vote with long term interests in mind. From observed and learned personal experience, they are willing to select directors whose goals prefer sustainable management of corporate resources and the prioritization of long-term corporate interests. ${ }^{173}$

169. Id. at 281.

170. Id. at 280 .

171. For example, the Cook Inlet Region Inc. (CIRI) ANC offers door prizes to encourage families to bring as many shareholders as possible, offers notaries and other services at meeting events, provides childcare, and often includes catered meals as incentives to gather members together. Shareholders and their spouses and children (even if not shareholders themselves) are welcome. CIRI Shareholder Handbook, CIRI, 22-23 (Sept. 12, 2016), http://www.ciri.com/wp-content/uploads/2016/09/SH-Handbook-2016.pdf. [https://perma.cc /UEX2-KWJZ].

172. I mean literally minor - shareholders under the age of 18 . Not shareholders with a minority share.

173. For a discussion of how the connection between culture and land encourages longterm thinking and action among Native Alaskan shareholders, see DAVID S. CASE \& DAVID 
There is no greater teacher than experience. Indigenous corporations' experiments with voting rights have provided a natural example of how changing the structure of corporate law will result in changes in corporate governance. Chthonic practices which favor the participation of the family, respect for elders, and stakeholder consultation have created a system that trains new shareholders how to be voters. By requiring that minors hold their shares until maturity in order to gain the right to vote the shares, ANCs have built a new kind of educated shareholder who has experience watching the decisions taken by the corporation over many years result in stronger outcomes for their community. The shareholder has thus learned to allow corporate management to invest in its stakeholders, to spend money on social and environmental protections which yield real benefits for Alaska Native villages and communities, and to accept higher costs associated with more employees and higher wages if those costs help achieve other social goods like full employment. Broad shareholder support for ANCs providing scholarship programs, medical services, and community care become engrained in corporate decision-making at least in part because the persons voting the shares themselves have long-term interests in the success of the corporation.

Corporate governance would be greatly improved if stock was not automatically imbued with voting rights but rather earned those rights only after being held by the same shareholder for a period of years. Such a system would not need to radically restructure markets. Shares could still be traded openly and for value. ${ }^{174}$ Each newly acquired share would still carry with it a proportional claim on the proceeds or profits of a corporate entity and would share in any dividend or distribution equally with those shares that had been held long enough to earn voting rights.

Implementing a system where shares gain voting rights only after they have been held for a specific term (eighteen years might be too long - say five or ten years) would necessarily require the development of new structures. Typically, one can tell what voting rights a share carries with it by looking at the share class. ${ }^{175}$ Some share classes will have voting rights

A. Voluck, Alaska Natives and American Laws 186-190 (2012).

174. John F. Walsh, Settling the Alaska Native Claims Settlement Act., 38 Stan. L. Rev. 227, 234-40 (1985) (discussing how under amendments made to ANCSA by the Alaska National Interest Lands Conservation Act ANCs could limit voting rights to Native persons and could purchase shares on offer from shareholders for their appraised value).

175. See generally Lynne Dallas \& Jordan Barry, Long-Term Shareholders and TimePhased Voting, 40 DEL. J. CORP. L. 541 (2016) (discussing the various types and levels of voting rights associated with different share classes); Olivia Wang, The Dual-Class Share Structure, 2 EMORY CORP. Governance AcCountability Rev. 63 (2015) (discussing attributes of dual-class stock structures, presenting often a double-edged sword impact on the 
and other will not. ${ }^{176}$ This is a variation of time-phased voting, (an idea explored by other corporate law scholars) ${ }^{177}$ except that instead of gaining additional votes for holding shares for a longer period, shares "mature" from non-voting to voting shares. This proposal upends the existing system of dual-class stock by permitting shares within a class to carry voting rights depending on how recently they have been traded (i.e. how long they have been held by the shareholder). A corporation would need to know in advance of its annual meeting how many shares had voting rights and who its voting members were. This is reasonable, but hardly a barrier to corporate law reform.

Most ANC shares are not freely traded ${ }^{178}$ and so new structures would need to be developed to track the voting status of any given share at any given time outside the Indigenous corporate model. This should not be overly burdensome. Corporations are already required to know basic information about the holders of their shares in order to send proper notifications and pay dividends. ${ }^{179}$ It would be a simple enough exercise to name an "ex-date"180 and to assign voting rights to shares held for Y number of years as of $\mathrm{X}$ date. Dividend payments are already calculated this way. ${ }^{181}$

By issuing shares with voting rights that mature after being held for a

company and its shareholders).

176. Dallas \& Barry, Long-Term Shareholders and Time-Phased Voting, supra note 174, at 547 (discussing time phased voting and suggesting that how long a share is held will determine how many votes it gets).

177. See Dallas \& Barry, Long-Term Shareholders and Time-Phased Voting, supra note 176, at 547 (discussing the opinions of proponents and skeptics of time-phased voting); See generally David J. Berger, Steven Davidoff Solomon \& Aaron J. Benjamin, Tenure Voting and the U.S. Public Company, 72 Bus. Law. 295 (2017) (discussing tenure voting as an alternative capital structure to a dual-class capital structure); Paul H. Edelman, Wei Jiang \& Randall S. Thomas, Will Tenure Voting Give Corporate Managers Lifetime Tenure?, 97 TEX. L. REV. 991 (2019) (discussing whether tenure voting is or isn't a better choice for corporate management and shareholders than dual-class stock).

178. Alaska Native Claims Settlement Act Amendments of 1987, Pub. L. No 100-241, 101 Stat. 1788, 1790 (1988) (codified as amended at 43 U.S.C. $\$ 1626(c)$ ) (discussing the fact that the initial restriction on the alienation of ANC shares is extended until a majority of shareholders vote to lift the restriction). See also Travis Buchanan, One Company, Two Worlds: The Case for Alaska Native Corporations, 27 AlaskA L. REV. 297, 301 (2010) (discussing the fact that majority of ANC's have permanent restrictions on tradability of the ANC's shares unless the shareholders vote to lift such restriction).

179. See generally James J. Park, Shareholder Compensation as Dividend, 108 Mich. L. REV. 323 (2009) (discussing inefficiencies of the process where companies pay dividends as compensation to shareholders).

180. Alicia J. Davis, The Institutional Appetite for 'Quake Corporate Governance', 2015 Colum. Bus. L. Rev. 1, 51 (2015) (discussing dividend to equity rations and noting in footnote 203 that dividends are awarded to shareholders on the "ex date.")

181. Id. 
fixed period, the pool of shareholders will necessarily change. Shareholders would no longer be able to buy a stock and instantly threaten to use their shares to drive leadership changes unless dividends increased or costs were slashed. Instead, only those who have held the shares long enough for voting rights to mature, and are therefore the most vested and presumably the best informed about the corporation and its strategic direction, are the ones who will have the votes to elect the Board. These long-term shareholders have the same vantage point as the ANC shareholders who have held their shares since childhood; they have had the opportunity to attend shareholder meetings and review corporate disclosures for years and are in the best position to judge when short term profits may be sacrificed for other noble ends.

\section{Shares with Variable Voting Rights}

Implementing shares with voting rights that mature over time is not the only available change to corporate law based on autochthonous principles to encourage corporate governance to be more responsive to its stakeholders and shake off the ills of short-termism. Reform must also ensure that a minority of shareholders cannot assert absolute control over a corporation. ${ }^{182}$

One of the unusual structures of Indigenous corporations compared to their non-Indigenous counterparts is their preference for a representational democratic structure. Alaska Native Corporations issue no more than 100 shares to any member. ${ }^{183}$ Corporations structured by the IRA are often responsible to the tribal council, or to a Board appointed by tribal council. ${ }^{184}$

182. These ideas are not unheard of in traditional corporate law, they are just very rare. See Providence \& Worcester Co. v. Baker, 378 A.2d 121, 123-24 (Del. 1977) (Cited in Unilever Acquisition Corp. v. Richardson-Vicks Inc., 618 F. Supp. 407, 409-410 (S.D.N.Y. 1985) ("[W]here authorized for over one hundred years by corporate charter, large stockholders may be restricted to fewer votes per share than small stockholders")).

183. 43 U.S.C. $§ 1606(\mathrm{~g})(1)(B)(i i)$ ("Not more than one hundred shares of Settlement Common Stock shall be issued to any one individual pursuant to clause (i)"). See also Marilyn J Ward Ford, Twenty Five Years of the Alaska Native Claims Settlement Act: Self Determination or Destruction of the Heritage, Culture, and Way of Life of Alaska's Native Americans?, 12 J. EnVtL. L. \& Litig. 305 (1997) (discussing how the 100 shares were distributed among certain Alaska Natives).

184. Michael M. Pacheco, Toward a Truer Sense of Sovereignty: Fiduciary Duty in Indian Corporations, 39 S.D. L. REV. 49, 88 (1994) ("To be fair and just, the governance of an Indian corporation should be the result of the collective effort of tribal members. It is the collective will of the tribe that can best assure that the tribe's corporate conduct is in accord with traditional tribal customs and beliefs."). See also Douglas M. Branson, Still Square Pegs in Round Holes? A Look at ANCSA Corporations, Corporate Governance, and Indeterminate Form or Operation of Legal Entities, 24 Alaska L. Rev. 203, 235 (2007) 
Councilors are in turn elected by a majority of the electorate in an election in which every voting member has one vote. In this way, every tribal member has an equal say in the direction of an IRA entity. Indigenous communities see this as a distinct feature of corporate governance that requires the Indigenous entity to cater to the needs of at least a majority of its shareholders instead of being focused on a minority of shareholders who hold a majority of shares. ${ }^{185}$ Even corporations chartered under tribal business codes share this preference for giving the widest group of shareholders an interest in selecting the Board, as demonstrated by the Winnebago Business Code's preference for cumulative voting. ${ }^{186}$

This concern over majority control by a minority of shareholders does not mean that chthonic law should prevent some shareholders from owning more shares than others. As Maude Blair explains in the context of ANCs;

The stock can carry limited or no voting rights. This provision can be used to clarify that people who are issued multiple classes of stock would not have disproportionate voting power. For example, a corporation could create a class of non-voting stock for elders who would still be able to vote their original ANCSA stock, but not have more voting power by virtue of their age. ${ }^{187}$

In such a system, one class of shareholders (elders, for example) might own more shares and therefore be entitled to larger share of the distribution of corporate profits but would not have a disproportionate share of voting rights. ${ }^{188}$

How might these lessons apply to non-Indigenous corporate governance? Just like a share may or may not contain voting rights depending on how long it has been held, a share may or may not contain voting rights depending upon how many other shares the owner possesses. This article does not attempt to set a threshold but instead articulates a principle; the goal is to ensure that no substantial minority of shareholders would acquire so many voting rights as to control the Board in a way which

("A corporation is merely a form of organization. In this day and age, a Native American tribe functions as if it were organized as a corporation. The council of elders serves as a board of directors, and the chief or head person much as a corporate CEO. The days in which no democracy among members is heeded are gone.").

185. Glenn, supra note 58, at 64-65.

186. Winnebago Business Corporation Code, supra note 63, at 2.

187. Maude Blair, Issuing New Stock in ANCSA Corporations, 33 AlasKa L. Rev. 273, 281 (2016).

188. Id. ("The non-voting elders stock could, however, entitle them to a larger pro rata dividend or a special elders' distribution."). 
may disadvantage the majority of shareholders (albeit a majority of shareholders who together own a minority of shares). Perhaps a three percent or five percent threshold would be sufficient, but that number should be tested and subject to rigorous scrutiny.

In such a system, any investor would still be incentivized to obtain more shares beyond the threshold selected to cut off voting rights because every share - regardless of whether voting rights attach - includes a claim to a pro rata portion of corporate proceeds. An investor who is interested in the returns offered to shareholders has every incentive to continue to accumulate shares even if those new shares are above the ownership threshold and therefore will not mature voting rights, no matter how long they are held. While corporate law scholars might raise concerns that treating a shareholder differently merely because it already holds a substantial portion of shares is discriminatory, ${ }^{189}$ such a system can hardly be deemed unfair when the rules for voting rights are clearly articulated in advance. ${ }^{190}$

Moreover, real change, the kind necessary to truly reform corporate governance, will require this kind of out of the box, never-before attempted, radial approach. While today institutional investors may hold the majority of shares of many companies ${ }^{191}$ limiting the voting rights of those shares would substantially diversify the proportion of voters at annual meetings and have corresponding effects on the Boards that get elected. With Boards becoming more responsive to a greater portion of shareholders, (and if maturity is also adopted, more focused on long-term shareholders) stakeholder interests have a greater chance of rising to the fore and commanding the force and attention of management.

I recognize that this proposal is merely the outline of what is possible

189. The Delaware Supreme Court has upheld such a scheme as a restriction on the stockholder and not as a restriction on the stock itself. See Providence \& Worcester Co. v. Baker, 378 A.2d 121 (Del. 1977) (holding valid the company's voting restriction being placed on the stockholder rather than the individual stock). Scholars are divided on this approach. See Victor Brudney, Equal Treatment of Shareholders in Corporate Distributions and Reorganizations, 71 CALIF. L. REV. 1072 (1983) (concluding that a rule of unequal sharing is unfair); James D. Cox, Equal Treatment for Shareholders: An Essay, 19 CARDozo L. REv. 615 (1997) (discussing that, in terms of unequal voting right assignment among classes of stocks, "the courts must commit themselves more aggressively to the statutory principle that the board of directors' discretion is restricted by the contractual rights of stockholders", for the better or worse).

190. Daniel DeFrancheschi, Written Consents - A Powerful Tool in Hostile Battles for Corporate Control, 14 DEL. J. CORP. L. 967 (1989) (discussing the role that consent plays to alter shareholder terms and create unique corporate structures).

191. Dov Solomon, The Voice: The Minority Shareholder's Perspective, 17 NEv. L. J. 739, 750-51 (2017) (remarking on the trend of disproportionate growth in the portion of shares owned by institutional investors, sixty-eight percent of all shares as of 2015). 
in the area of reforming voting rights. I also recognize that as sophisticated actors, institutional investors create multiple holding vehicles, shell companies, or proxy shareholders in order to avoid losing the voting power of their shares. Both corporate $\operatorname{law}^{192}$ and Indian law ${ }^{193}$ have developed countervailing measures which would be relevant in policing shareholder behavior. Asking whether a shareholder is merely "an arm"194 or an "alter ego" 195 of another shareholder or institutional investor would provide an opportunity to collectively limit the voting rights of any coordinated group who really represent a singular interest. ${ }^{196}$ The implementation of such a robust policing system of voting rights is rightly the subject of future scholarship. The essential point to be made here is that both the maturity of voting rights and limitations on the voting rights of shares of any single shareholder are principles found in chthonic law, already deployed by Indigenous corporations, and have the potential to change the nature of corporate governance to promote the interests of stakeholders and the institutionalization of long-term thinking among managers and directors.

\section{Ownership Rules}

Changing the voting rights of corporate shares may not be enough to encourage corporate behavior to sacrifice some profits for higher wages, community support, or environmental sustainability. Accordingly, chthonic legal principles also suggest a pair of changes to ownership rules; (1) Ensuring that all stakeholders have an ownership interest in the corporation, and (2) Eliminating the fiction that shares exist indefinitely.

192. Richard Farmer, Parent Corporation Responsibility for the Environmental Liabilities of the Subsidiary: A Search for the Appropriate Standard, 19 IOWA J. CORP. L. 769, 774 (1994) (discussing when corporate law can treat a parent and its subsidiary as functionally the same legal entity).

193. Patrice H. Kunesh, Tribal Self-Determination in the Age of Scarcity, 4 S.D. L. REV. 398, 402-3 (2009) (discussing the legal test for separating an IRA entity from a tribal entity).

194. Id.; People v. Miami Nation Enters.', 2 Cal. 5th 222, 256 (Cal. 2016) (discussing that entities which act as an arm of the tribe are indistinct from the tribe itself and so treated as stemming from the same sovereign origin). See also Breakthrough Mgmt. Grp. v. Chukchansi Gold Casino \& Resort, 629 F.3d 1173 (10th Cir. 2010) (discussing when an entity or a shareholder might be seen as "an arm" of a tribe).

195. Mary Elisabeth Kors, Altered Egos: Deciphering Substantive Consolidation, 59 PITT. L. REV. 381, 390 (1998) (discussing the origins of piercing the corporate veil and the factors used to determine whether one entity is the alter ego of another).

196. Id. 


\section{Stakeholder Ownership}

This first proposal, to ensure corporate stakeholders are also shareholders, is by no means limited to Indigenous corporations - although autochthonous law has some interesting corollaries. Corporate behavior necessary changes when stakeholders become shareholders. ${ }^{197}$ When employees and community members are also corporate shareholders their interests in robust labor standards, higher employee wages (living wages), environmental protection, and improving general working conditions are also elevated as corporate priorities. ${ }^{198}$

European corporate law has long recognized the important connection between voice ${ }^{199}$ and policy. ${ }^{200}$ While not necessarily requiring corporations to give a share of their proceeds directly to employees, many EU nations mandate that some seats on corporate boards be reserved for labor or represent the interests of workers. ${ }^{201}$ When employees are represented in the Board Room, corporate decision making changes. ${ }^{202}$ Management generally becomes more flexible in its willingness to pay living wages, to invest in training, and to become more responsive to the needs of the communities in

197. Thomas C. Beierle \& Rebecca J. Long, Chilling Collaboration: The Federal Advisory Committee Act and Stakeholder Involvement in Environmental Decisionmaking, 29 ENV'T. L. REP. 10399, 10399-40 (1999) (discussing the role that stakeholders play in changing corporate behavior, and in particular in pushing for environmentally sustainable practices).

198. Id.

199. Voice has become a theoretical construct indicating that a group is physically represented on a Board and that they have a voice at the table to ensure their concerns are heard by the directors. See Katharine Jackson, Toward a Stakeholder-Shareholder Theory of Corporate Governance: A Comparative Analysis, 7 Hastings Bus. L.J. 309, 343 (2011)

("[T]he interests of stakeholders and stockholders can be accounted for in a consistent and cohesive manner without having to pick sides. Such theories can be used to justify the incorporation of stakeholder voices into corporate decisionmaking. When viewed together, the theories of corporate governance also tend to support this incorporation by taking advantage of stakeholders' role as corporate stockholders.").

200. See id. at 353 (discussing German corporate law's requirement that representatives from labor be placed on corporate boards).

201. Id.; see also Sanford M. Jacoby, Employee Representation and Corporate Governance: A Missing Link, 3 U. PA. J. LAB. \& EMP. L. 449, 458 (2001) ("In Europe and Japan, corporate governance takes into account the interests not only of shareholders but of suppliers, customers, and employees, as well.").

202. See id. at 462-63 ("Employee voice is achieved through informal processes as well as formal representation. . . The prevailing ethos in top management is to give heavy priority to layoff avoidance and, in fact, managers who safeguard employee jobs are rewarded with higher salaries.”). 
which corporations are located. ${ }^{203}$ All of these are goals consistent with chthonic law.

The International Labor Organization (ILO) goes further. ILO Conventions have a unique tripartite structure that includes representatives from labor, management, and government in order to resolve disputes. ${ }^{204}$ Elevating labor to an equal footing with management, and subject to the auspices of law, encourages compromise and problem solving that can be responsive to the needs of a corporation to continue to operate profitably while simultaneously protecting the interests of non-shareholding stakeholders. $^{205}$ There are even a couple ILO conventions structured to protect the rights of Indigenous people, creating some interesting models for corporate-Indigenous relations. ${ }^{206}$

While there is some scholarship promoting a mandatory role for labor on the Boards of American companies, ${ }^{207}$ the lessons learned from Indigenous corporations suggest a slightly different approach to accomplish the same ends. Rather than mandate Board seats for some preordained constituency, all stakeholders should become shareholders. ANCs do this already, with each member eligible to be issued up to 100 shares of stock and shares eligible to be issued upon the birth or enrollment of new members. ${ }^{208}$ IRA corporations do this indirectly by typically giving all tribal members the right to vote for members of Council and giving Council the role to appoint

203. See Kimberly Goldman, Theories and Solutions on Wolf Pack Activism, 7 Mich. Bus. \& ENTREPRENEURIAL L. REV. 341, 343 (2018) (discussing how shareholder primacy-focused directors (the "wolf pack") are less responsive to stakeholder interests).

204. See Laurence R. Helfer, Understanding Change in International Organizations: Globalization and Innovation in the ILO, 59 VAND. L. REV. 649, 651-52 (2006) (providing extensive discussion on the unique tri-partite structure of the ILO).

205. See id. at 677 (discussing the rights that international labor standards give to independent workers' and employers' groups).

206. S.J. Rombouts, The Evolution of Indigenous Peoples' Consultation Rights under the ILO and U.N. Regimes, 53 STAN. J. INT'L L. 169, passim (2017) (discussing ILO 169, the Indigenous and Tribal Peoples Convention). ILO 107 was a precursor to 169 and also dealt with the rights of Indigenous people. See Michael Halewood, Indigenous and Local Knowledge in International Law: A Preface to Sui Generis Intellectual Property Protection, 44 McGiLl L.J. 953, 966-67 (1999) (discussing ILO 107).

207. See, e.g., Michael Harper, Reconciling Collective Bargaining with Employee Supervision of Management, 137 U. PA. L. REV. 1, 2 (1988) (“The employees' supervisory power can be exclusive, or it can be shared, to varying degrees, with nonemployee investors. For the traditional corporate firm, this strategy includes some level of employee representation on the firm's board of directors."); Danielle M. Kinchen, Look to Your Left, Look to Your Right: Why the SEC Should Reserve Seats at the Boardroom Table for Shareholder Nominees, 20 U.C. Davis Bus. L.J. 1 (2019); Michael Lower, John Paul II and Employee Participation in Corporate Governance, 21 ND J.L. ETHICS \& PUB. POL'Y 111, 157 (2007) (noting the potential benefits of employee representation in the boardroom).

208. Blair, supra note 108, at 278, 280. 
members of the Board, ${ }^{209}$ or alternatively having all tribal members vote directly for the directors of their corporations. ${ }^{210}$

Some companies already make at least some of their employees shareholders through retirement schemes like 401(k) plans, which hold at least some of their assets (typically a corporate match) in shares. ${ }^{211}$ However, in most such systems, the trustee for the plan votes the shares in the best interest of the plan participants. ${ }^{212}$ This is problematic. It fails to achieve the goal of Indigenous governance by making the shareholders active participants in the management of the company. Individual employees may also have variable interests, and a single trustee is a poor voice to represent the diversity of interests embodied within the community of plan participants. ${ }^{213}$ Instead of shielding stakeholder ownership through complicated legal devices, it is considerably more democratic (if administratively more burdensome) to allow employees to hold shares directly. By universally empowering employees as shareholders, the Board will be even more responsive to the needs of its constituents, and in lieu of having a minority of Board seats reserved for these interests - a majority of the Board may ultimately owe their seats to stakeholder votes.

209. See Jason Hipp, Rethinking Rewriting: Tribal Constitutional Amendment and Reform, 4 COLUM. J. RACE \& L. 73, 80-81 (2013) (IRA tribes typically use majority voting to select Tribal Council).

210. Sebastian Braun, Grant Christensen, \& Birgit Hans, American Indian Studies: Historical to CONTEMPORARy Perspectives 22 (2017)

("The Catawba Indian Nation does have a Constitution but instead of an elected legislative branch the tribe employs a general council in which every adult member participates directly. The general counsel elects an executive committee with the power to enforce the laws. Under the Catawba Constitution, the general council is the only entity that can negotiate with the state or federal government, it can veto the sale of tribal lands, and pass tribal ordinances.").

211. Employee compensation using shares is a common compensation structure that has taken a variety of forms and has been challenged regularly in court. See Craig C. Martin \& Elizabeth L. Fine, ERISA Stock Drop Cases: An Evolving Standard, 38 J. MARSHALl L. Rev. 889,889 (2005) ("Companies that made stock available to their employees through any of a number of options, including Employee Stock Option Plans ("ESOPs"), matching programs under 401(k) plans, or simply allowed employees to choose employee stock as an investment option in the 401(k) plans all saw ERISA suits.").

212. See id. at 899 .

("The duty of loyalty applies in situations where the fiduciary is faced with a potential conflict of interests, such as the situation where the trustee of a pension plan also has responsibilities to the entity (e.g., employer or union) sponsoring the plan. Thus, litigation of the duty of loyalty has arisen most often in the context of self-dealing transactions, such as where a plan's fiduciary uses plan assets to benefit non-beneficiaries.").

213. Id. 
Chthonic law provides one more suggestion: nature as a shareholder. If the goal of stakeholder ownership is to make corporate governance more responsive to the communities it serves, then the stakeholder class should not be limited only to employees. Nature itself is a powerful stakeholder, directly impacted by the decisions of individuals and corporations within its catchment. Indigenous communities and autochthonous traditions regularly recognize the rights of nature in various forms. ${ }^{214}$ The Klamath River or Manoomin (wild rice) may exercise rights separate from any individual under Yurok ${ }^{215}$ or White Earth Ojibwe ${ }^{216}$ traditions. If corporate law were to evolve along these autochthonous lines and require that a portion of every corporation's shares be held by nature itself, management would prioritize the environmental effects of its policies very differently. A new world of shareholder action would emerge with nature having clear standing to challenge corporate policies that were incongruous with sustainability. A world where nature itself is a shareholder of every publicly traded corporation is a radical departure from modern corporate law, but such a world has the potential to realign management incentives and transform corporate governance.

\section{Corporate Shares as Life Estates}

In addition to making stakeholders into shareholders, chthonic law suggests one additional change to corporate law and the limitation on ownership - the ultimate death of shares. As this Article has demonstrated, Indigenous principles auger against the power of a small minority of shareholders controlling the direction of a corporation. ${ }^{217}$ Egalitarianism and

214. See, e.g., Caroline McDonough, Will the River Ever Get a Chance to Speak? Standing Up for the Legal Rights of Nature, 31 Vill. ENV'T L.J. 143, 154-56 (2019) (discussing the Maori tribe's advancement of the rights of nature doctrine in New Zealand).

215. Thompson, supra note 129, at 13-14.

216. Rachel Durkee Walker \& Jill Doerfler, Wild Rice: The Minnesota Legislature, a Distinctive Crop, GMOs, and Ojibwe Perspectives, 32 HamLIne L. ReV. 499, 509-11 (2009).

217. See Christine Zuni Cruz, Toward a Pedagogy and Ethic of Law/Lawyering for Indigenous Peoples, 82 N.D. L. Rev. 863 (2006)

("Self-determination is ... grounded in the idea that all [peoples] are equally entitled to control their own destinies. Self-determination gives rise to remedies that tear at the legacies of empires, discrimination, suppression of democratic participation, and cultural suffocation. ... We are autochthonous, a term used in describing people who live by being chthonic, that is by living in or in close harmony to the earth. Our legal tradition can be described as autochthonous legal tradition. The chtonic legal tradition rejects formality in the expression of law and is characterized by the oral tradition. Even as we move into this new millennium, we are still people grounded in the land."). 
democratic governance are at the heart of chthonic law. ${ }^{218}$ Building off of the model of Alaska Native Corporations, this Article suggests reimagining shares as property possessed during the duration of a natural life, and thus protecting against the accumulation of shares by a small but motivated minority.

ANCs issue shares which are not generally heritable. As Maude Blair explains, "Making stock a life estate keeps the overall number of shares much lower ... thereby allowing less dilution. It also limits the voting power that any one shareholder can accumulate." 219 While American law ordinarily would require some compensation to a shareholder for the loss of their property, ANCSA has pioneered an experiment whereby Congress has given its explicit approval to countenance the death of shares. "Generally in corporate law, an individual must be compensated for the taking of property, such as stock in a corporation. But ANCSA allows life estate stock to revert to the corporation with no compensation to the deceased shareholder's estate." $^{220}$ The benefits of a limited life for shares include the disincentivizing of rent seeking, a hedge against accumulated/inherited wealth, and greater diversity of ownership. ${ }^{221}$

The idea of a "life estate" in shares works for ANCs (and relatedly for IRA corporations) $)^{222}$ in part because shareholders are all individuals. Transposing such a principle into modern corporate law will require more finagling since shares may be owned by other corporations or institutions that are essentially undying under the principles of American law. ${ }^{223}$ A strict application of the life estate principle would see individual shareholders lose their shares over time while shareholding entities accumulate larger and larger slices of corporate profits even as their management is slowly changed and replenished over decades.

Rather than imbue shares with a non-heritability clause, the principle of

218. Id.

219. Blair, supra note 108 , at 281.

220. Id.

221. Id. ("Making stock a life estate keeps the overall number of shares much lower than it would be if all stock were inheritable, thereby allowing less dilution. It also limits the voting power that any one shareholder can accumulate.").

222. Since IRA corporations are subject to the decisions undertaken by tribal council, every member's vote to control the corporation begins when they reach the age at which franchise is extended and ends with the member's natural death.

223. Crafford v. Bd. of Supervisors, 12 S.E. 147, 148 (Va. 1890) ("Corporations are to be deemed and considered as 'persons,' when the circumstances in which they are placed are identical with those of natural persons expressly included in such statutes.") (quoting Beaston v. Farmers' Bank of Del., 37 U.S. 102, 134 (1838). For an academic discussion of this legal fiction, see generally Elizabeth Pollman, A Corporate Right to Privacy, 99 MinN. L. REv. 27 (2014). 
the life estate might be preserved by issuing shares that represent a share of corporate profits only for a set number of years - perhaps eighty, the rough life expectancy of an American today. ${ }^{224}$ Shares could be freely traded, inherited, used as a security, and/or gifted away during their natural eightyyear life but upon reaching eighty years the shares are retired. Essentially, the shares escheat to the corporation. ${ }^{225}$ The corporation can then choose to reissue them, or it can choose to retire the shares and thus increase the value of all remaining shares proportionately.

Such a reform would obviously raise due process concerns if it were retroactively imposed on all existing shares. Instead, the natural life of shares might be implemented on all new stock issued by a corporation, and incentives created for corporations to buy and retire older shares. It would take more than a generation for most large entities to replace their existing pool of shares, but the adoption of the reform (even if implemented over a longer timescale) would immediately raise the profile of issues of concern to minority shareholders and the social injustices perpetuated by inherited wealth.

\section{CONCLUDING OBSERVATIONS}

There is very little extant work on Indigenous conceptualizations of the corporation. In America, it is hard to imagine that Indigenous people thought about the separation of wealth from labor until the structure of the first joint stock companies were explained to them. The Virginia Company, a pair of such organizations chartered by James I of England to encourage the settlement of North America, ${ }^{226}$ would have seemed an unnatural and unwanted creature that required its employees to take unconscionable risk while awarding itself and its investors an outsized share of the profits of empire. $^{227}$

224. Nat'l Ctr. for Health Stats., Life Expectancy, CTRS. FOR DiseASE CONTROL \& PREVENTION, https://www.cdc.gov/nchs/fastats/life-expectancy.htm) [https://perma.cc/5SQC -PJJA] (last visited Apr. 10, 2021) (reporting that the average life expectancy of an American is 78.7 years).

225. See Lawrence Hamermesh, Calling Off the Lynch Mob: The Corporate Director's Fiduciary Disclosure Duty, 49 VAND. L. REV. 1087, 1111 n.92 (1996) (discussing a similar situation presented by State v. Jefferson Lake Sulphur Co., 178 A.2d 329 (N.J. 1962), wherein dividends from unknown shareholders could escheat to corporation after a fixed period of time and reasonable effort to locate the beneficiary).

226. See generally Finbarr McCarthy, Participatory Government and Communal Property: Two Radical Concepts in the Virginia Charter of 1606, 29 U. Rich. L. REV. 327 (1995) (discussing the origins of the Virginia Company, its charter, and its perspectives on governance).

227. See id. at 333 ("Consequently, the initiating documents substantially determined who 
In time, Indigenous groups came to re-appropriate the corporate device, keeping some of its basic mechanics but radically redesigning everything from its structure to its purpose. ${ }^{228}$ The result was the development of Indigenous corporations subject to autochthonous legal principles. Today, the world of corporate law and corporate governance is seeking alternatives to the shareholder primacy model of governance that has held sway for a century. The American people are demanding changes in corporate behavior, and to accomplish them corporate structures must evolve. ${ }^{229}$

This article has articulated a way forward. By drawing upon chthonic law and Indigenous corporate traditions, it suggests radical reforms to remake American corporate governance through an autochthonous lens. The elimination of short-term thinking and incentives, the restructuring of voting rights among shares and shareholders, and limitations on ownership itself will together create a new legal structure which prioritizes the interests of stakeholders (labor, communities, and the environment) while not jeopardizing the need for corporations to profitably earn returns for shareholders.

This article began with an observation from former Navajo Supreme Court Justice Raymond Austin: "Leaders of Indian nations must understand that long-standing tribal values, customs, and traditions are sources for problem-solving, not only in the legal arena but also in areas like health and social welfare, education, and government." ${ }^{, 230}$ In this moment that calls out for corporate governance reform it is not only tribal leaders but corporate leaders who can turn to Indigenous values to meaningfully alter corporate governance in ways that are environmentally and socially responsible.

confronted the dangers of colonizing and who would ultimately profit from the undertaking.").

228. See supra Part III (discussing the emergence of Indigenous conceptions of the corporation through the Indian Reorganization Act, the Alaska Native Claims Settlement Act, and autochthonous law).

229. See supra note 6 .

230. Raymond Austin, American Indian Customary Law in the Modern Courts of American Indian Nations, 11 Wyo. L. REV. 351, 354 (2011). 